\title{
The Economics of Modern Imperialism
}

\author{
Guglielmo Carchedi \\ Professor Emeritus, Department of Economics and Econometrics, \\ University of Amsterdam, Amsterdam, The Netherlands \\ carchedi38@gmail.com \\ Michael Roberts | ORCID: 0000-0002-0929-3044 \\ Independent Researcher \\ bobmckeeg9@yahoo.com
}

\begin{abstract}
This work focuses exclusively on the modern economic aspects of imperialism. We define it as a persistent and long-term net appropriation of surplus value by the high-technology imperialist countries from the low-technology dominated countries. This process is placed within the secular tendential fall in profitability, not only in the imperialist countries but also in the dominated ones. We identify four channels through which surplus value flows to the imperialist countries: currency seigniorage; income flows from capital investments; unequal exchange through trade; and changes in exchange rates.

We pay particular attention to the theorisation and quantification of international UE and of exchange-rate movements. Concerning UE, we extend Marx's transformation procedure to the international setting. We use two variables in the analysis of UE: the organic composition of capital and the rate of exploitation, and we measure which of these two variables is more important in contributing to UE transfers. We research a time span longer than in any previous study. We also introduce the distinction between narrow and broad unequal exchange according to whether two countries are assumed to trade only with each other or also with the rest of the world.

As for the analysis of the exchange rates as a channel for appropriation of international surplus value, we reject conventional approaches because they are rooted in equilibrium theory. We find very strong empirical evidence that exchange rates tend towards the point at which the productivities are equalised. This is only a tendency because this equalisation is inherently incompatible with the nature of imperialism.

Finally, given its topicality, we apply our analysis to the relation between the US and China and find that China is not an imperialist country according to our definition and data.

(C) GUGLIELMO CARCHEDI AND MICHAEL ROBERTS, 2021 | DOI:10.1163/1569206X-12341959

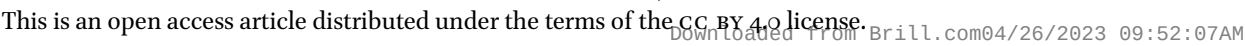




\section{Keywords}

imperialism - value - international trade - unequal exchange

\section{Introduction}

This work does not aim at submitting a general or complete theory of imperialism. Nor is it a review or assessment of present and past debates on imperialism. ${ }^{1}$ Nor does it aim at providing an exhaustive coverage of all the relevant issues. The aspects of modern imperialism dealt with here are far from being comprehensive. Our focus is on some key new economic and financial traits of modern imperialism with special emphasis on the relations between the imperialist and the dominated countries through the prism of Marx's labour theory of value.

Our stress on modern imperialism does not deny the persistent existence of colonialism. Colonialism and modern imperialism do not exclude each other. Colonialism is the appropriation of natural resources, military occupation, the direct state control of colonies and the stealing by the imperialist countries of commodities not produced capitalistically. But colonialism contains in itself the germs of modern imperialism. This is the appropriation by capitals in the imperialist countries of the surplus value produced by capitals in the colonies through the trade of the commodities with high technological content produced in the imperialist countries for the capitalistically produced raw materials or industrial goods produced with lower technological content in the dominated countries. The result is unequal exchange (henceforth, $U E$ ), the appropriation of international surplus value through international trade. This modern form of appropriation of international surplus value is not absent in colonialism. But it is not the most important one. Modern imperialism penetrates and develops within colonialism until it becomes the dominant form. Under modern imperialism, technology has become the new battlefield.

The above could be misinterpreted as economism. But this charge would be unwarranted. We focus on the economy's determining features, which make possible the existence of other extremely important, but determined traits, like military and political domination, as well as cultural and ideological pre-eminence. ${ }^{2}$ These other features are not simply added to the economic

1 Here we would recommend Mavroudeas 2018 and King 2020.

2 Imperialism is much more than domination. Norfield 2018 uses "the term "imperialism" in the classical sense to describe the system of domination in the capitalist world economy.' But domination is the consequence of technological and thus economic superiority. 
ones in order to obtain a more complete picture. Their interrelation is dialectical. Particularly important, military and ideological supremacy is not simply an appendage of economic power. Rather, economic power is determinant because it is the condition of existence of the military and ideological power and the latter is determined because it is the condition of reproduction (or supersession) of the former. Military, political and ideological power, even if determined by superior technology and economic power, is essential for economic power's reproduction. ${ }^{3}$

The production and appropriation of international surplus value should be framed within the context of the post-wwiI tendential long-term fall in world profitability. This fall affects both the imperialist countries (henceforth, IC) and the dominated countries (henceforth, DC) even if in different measures. ${ }^{4}$

Official statistics focus on GDP rather than on profitability figures. Nevertheless, they are telling. They show the tendential fall of the world GDP growth rate (Figure 1).

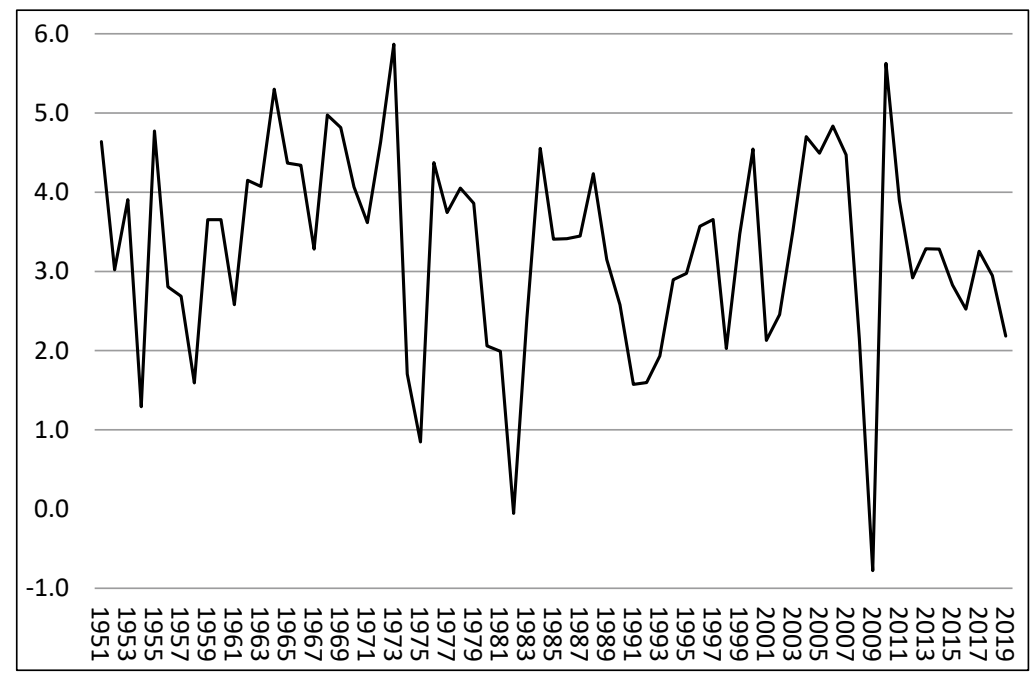

FIGURE 1 G2O countries' annual real GDP growth, 1950-2019 (\%) SOURCE: PENN WORLD TABLES 10.0, AUTHOR'S CALCULATIONS. PLEASE NOTE THAT ALL CALCULATIONS FOR THE FIGURES ARE EXPLAINED IN APPENDIXES 1 AND 2

3 For a discussion of the notion of the dialectical relation, see Carchedi 2011, Chapter 1.

4 We recommend Freeman 2019 for an approach complementary to the present one. 


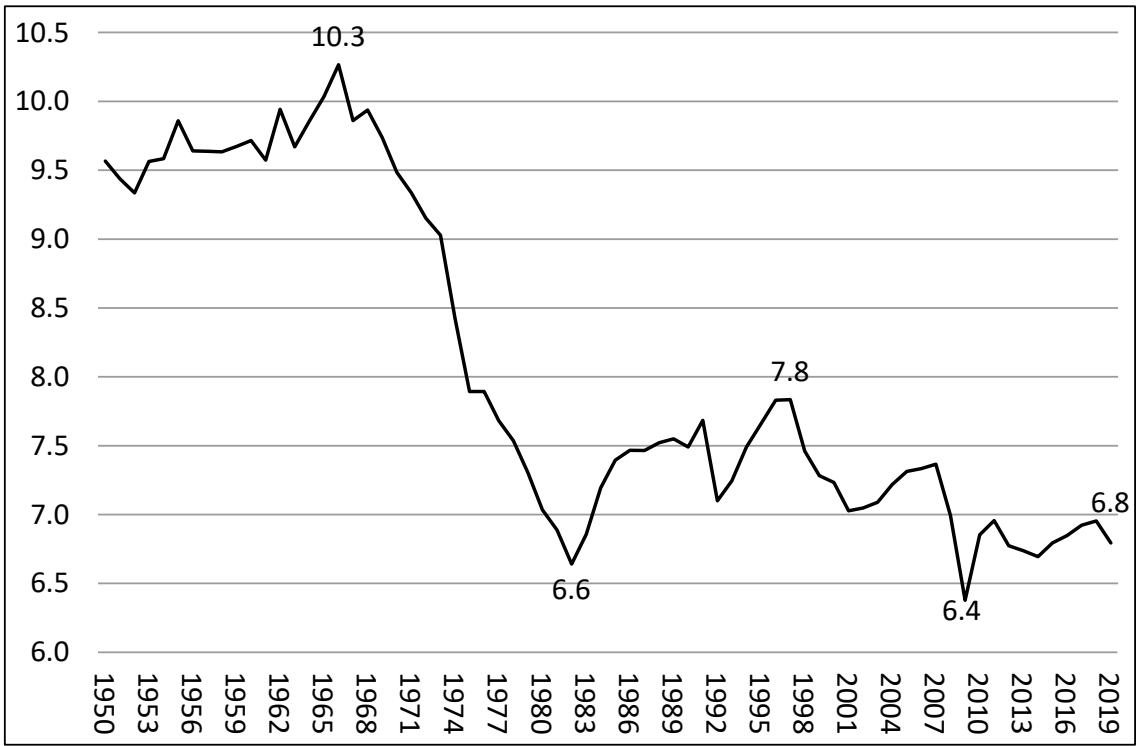

FIGURE 2 G2O rate of profit (\%)

SOURCE: PENN WORLD TABLES 10.0, AUTHORS' CALCULATIONS

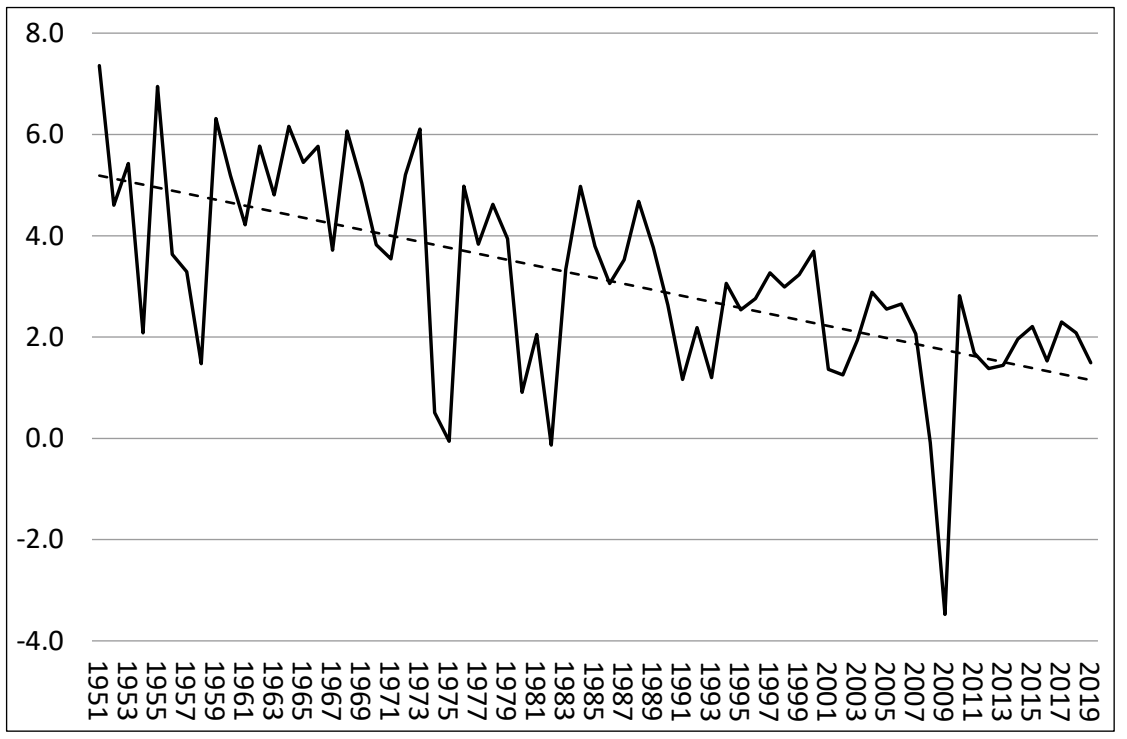

FIGURE 3 Annual real GDP growth in imperialist bloc (\%)

SOURCE: PENN WORLD TABLES 10.0, AUTHORS' CALCULATIONS

The falling rate of GDP growth for the G2o countries is puzzling to conventional macroeconomics. Usually, the culprit is found in falling consumer spending and investment growth. But this in turn must be explained. A further step back 
in the explanation focuses on changes in 'consumer confidence' and in 'animal spirits'. But these too must be explained. In the end, conventional macroeconomics' attempts to explain the falling rate of growth of GDP are nothing more than clutching at straws.

Not so in Marx's theory. In it, the key variable is the rate of profit. Put in its most general terms, if total assets grow, due to the labour-shedding nature of new technologies, employment grows less (or even falls) than the growth in total assets. Since only labour produces value and surplus value, less surplus value is generated relative to total investments. The rate of profit falls and less capital is invested. Thus, the rate of change of the GDP falls. This is not a linear movement, it is the tendency. There are also many counter-tendencies, especially the rising rate of surplus value. But empirical research shows that the latter cannot hold back the former (Figure 2).

The slowdown in real GDP growth is particularly notable for the imperialist bloc of countries (Figure 3$)^{5}$

This slowing trend in real GDP growth is matched by the secular decline in the profitability of capital in the imperialist bloc (Figure 4).

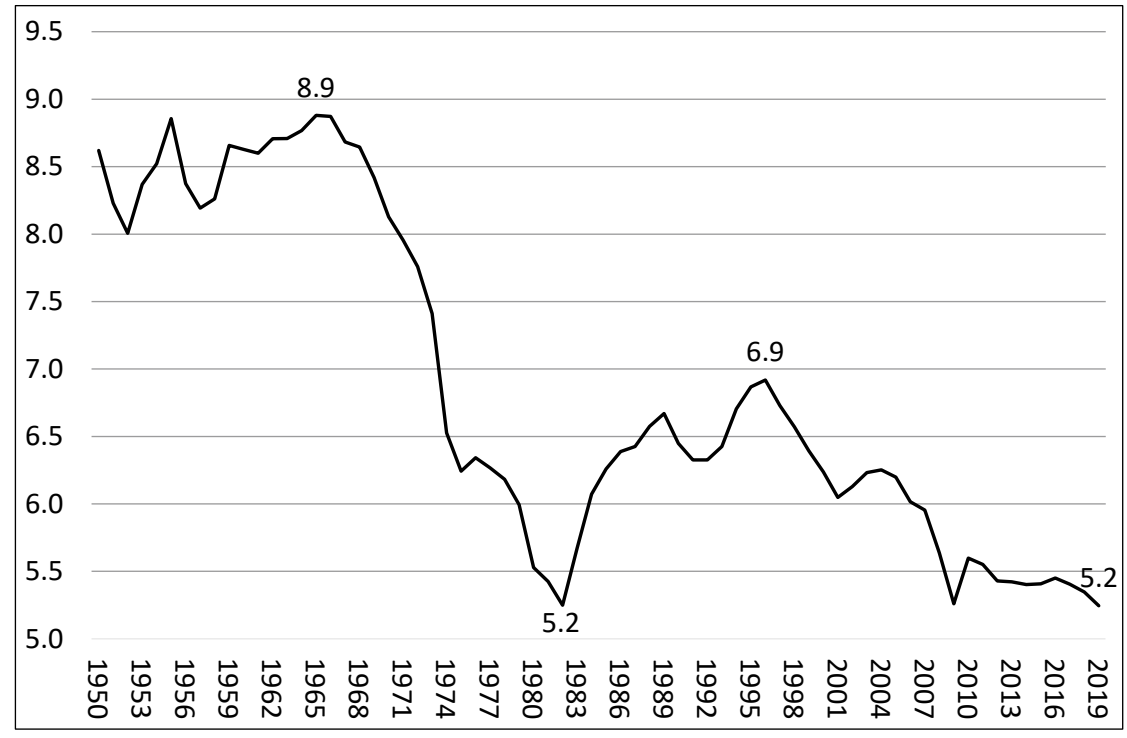

FIGURE 4 Imperialist bloc rate of profit (\%) SOURCE: PENN WORLD TABLES 10.0, AUTHORS' CALCULATIONS

5 We define the dominated countries as those in the G2O group that are not imperialist (11 countries). The imperialist countries are defined as the $\mathrm{G}_{7}$ plus Australia in the G2o bloc. There are other smaller imperialist countries in Europe, and New Zealand, but these are excluded in our calculations. 
The pie is growing ever more slowly. In the wake of this long-run persistent economic deterioration in both output growth and profitability, the imperialist countries are like hungry wolves, which when the game gets scarcer, not only take an extra chunk out of the weaker prey, but also increasingly cut each other's throats.

The inflow of surplus value into the imperialist countries from the rest of the world has helped to slow down the deterioration in output growth and profitability, but has not reversed it. The imperialist countries get a larger share of the shrinking quantity of surplus value at the cost of the dominated countries. But this larger share can reverse the fall in profitability only to the point at which this fall resumes. Nevertheless, the imperialist appropriation of surplus value through unequal exchange in trade (see below) is an important counter-tendency to the decreasing growth of surplus value in the imperialist countries. ${ }^{6}$

Thus, our task is not simply to document the thirst for surplus value of the so-called 'global North', but rather to explain this increasing thirst in terms of the progressive drying-up of the source of surplus value in the imperialist nations. These countries, to quench their thirst for profits, tap increasingly into the fountain of the dominated countries.

Marx focused mainly on the falling rate of profit within a nation. Within it, the national rate of profit falls because sectors compete by introducing labour-saving and productivity-increasing new technologies, thus raising the organic composition of capital (occ henceforth). We aim at extending Marx's analysis and applying it to international trade and investment between the imperialist and the dominated bloc. We consider explicitly the different rates of surplus value as one of the two basic determinants of UE.

Our empirical research reveals the specificity of the law of profitability under imperialism. The downward movement in profitability is due to the fact that (a) both blocs' rates of profit fall; (b) the dominated countries' profitability is persistently above that of the imperialist ones because of their lower occ; and (c) the dominated countries' profitability, while persistently higher than in the imperialist countries, falls more than in the imperialist bloc.

6 So we are in full agreement that 'an injection of surplus value by means of foreign trade would raise the rate of profit and reduce the severity of the breakdown tendency.... Marx's conception [that] the original surplus value expands by means of transfers from abroad ... thus we have a means of partially offsetting a crisis of valorisation in the domestic economy'. And 'at advanced stages of accumulation, when it becomes more and more difficult to valorise the enormously accumulated capital, such transfers become a matter of life and death for capitalism. This explains the virulence of imperialist expansion in the late stage of capitalism.' (Grossmann 1992, p. 172, quoted in Kuhn 2007, pp. 133-4.) 


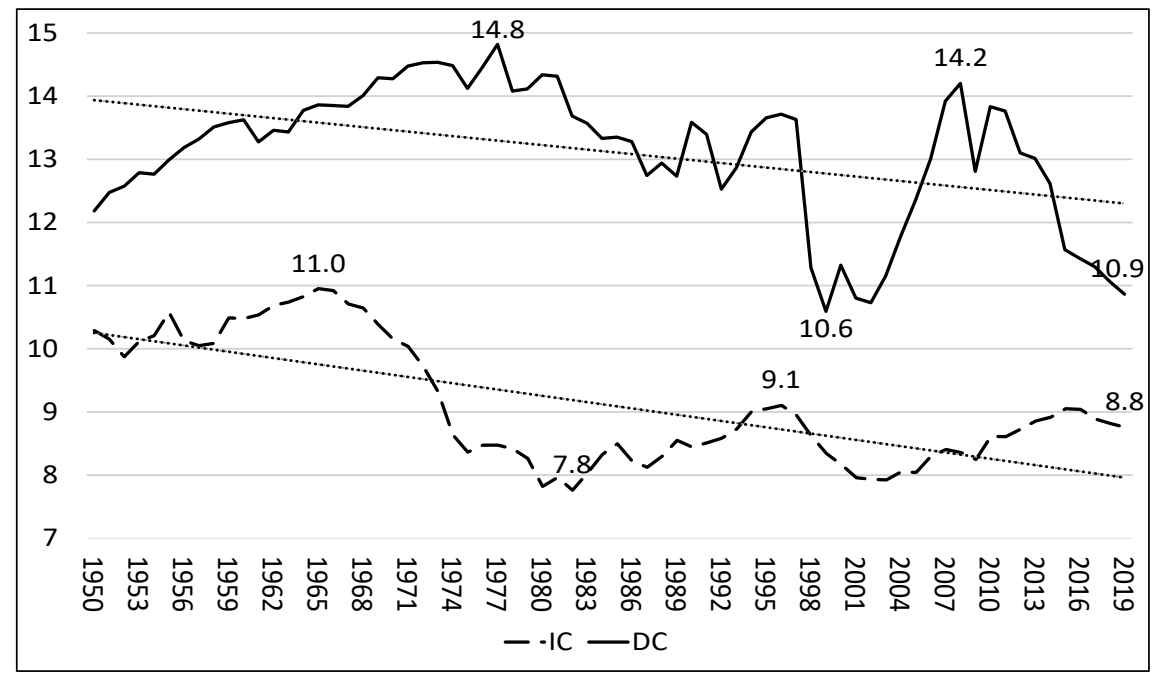

FIGURE 5 Rate of profit in imperialist and dominated blocs (\%) SOURCE: PENN WORLD TABLES 10.0, AUTHORS' CALCULATIONS

Since 1974, the rate of profit of the imperialist $\left(\mathrm{G}_{7}\right)$ bloc has fallen by $20 \%$, but the higher rate of the dominated bloc has fallen by $32 \%$. This leads to a convergence of the two blocs' profit rates over time (Figure 5).

Development economics argues for a convergence upward, i.e., that the 'under-developed' or 'emerging market' economies approach the level of wealth of the 'developed' ones. As Figure 5 shows, the two blocs do converge, but downwards in profitability. In spite of the different pace at which the rate of profit tends to fall in the imperialist and the dominated countries, the cause is the same, namely the inability of the counter-tendencies, especially of the increase in the rate of surplus value, to counter sufficiently the rise in the occ, as Marx's law of profitability argues. ${ }^{7}$

\section{$3 \quad$ Measuring Productivity}

In the Marxist analysis of modern capitalism and thus in this work, the focus is on competition through technological development. Capitals compete basically by introducing new techniques, which are incorporated into new means of production, or non-financial assets. New techniques on the one hand shed labour so that less value and surplus-value is produced. On the other hand, due

7 For Marx's law of profitability, see Carchedi and Roberts (eds.) 2019. 
to greater productivity, less labour produces a bigger output of use values. New technologies are both labour-shedding and productivity-increasing. The primary role of technological competition holds both within and between nations.

But between nations there is a new actor on the scene: the different countries' rates of exploitation. Here Marx introduces an important difference. While within a nation we can assume a tendential equalisation of the different sectors' rates of exploitation, 'On the universal market ... the integral parts are the individual countries. The average intensity of labour changes from country to country; here it is greater, there less. These national averages form a scale, whose unit of measure is the average unit of universal labour. ${ }^{8}$ So, if countries are considered, what counts is the average intensity, etc. of labour within each country. These national averages form a scale and thus do not aggregate in an international average because the factors that make possible the formation of an average within a country (labour's freedom of movement, trade unions, etc.) are inoperative across national boundaries. There is no tendential equalisation of the rates of surplus value in the universal economy. This bears directly on the notion of productivity.

Productivity is usually defined as GDP per unit of labour. This is unsuitable for our purposes. The numerator (GDP) can rise both because more advanced technologies increase the quantity of use values per unit of labour and because of an increase in the rate of exploitation, i.e., by raising the length of the working day and the intensity of labour. But only the former measures productivity. The latter measures exploitation. This is stressed by Marx: the productivity of labour 'is expressed in the relative extent of the means of production that one worker ... turns into products. ${ }^{9}$ There is no mention of the effect of exploitation on output.

So, assets must replace GDP in the numerator of the productivity ratio. This is the ratio of the mass of assets per unit of labour. This is what Marx calls the technical composition of capital (henceforth, TCC). Since new technologies are productivity-increasing but labour-shedding, the TCC tends to grow.

However, if assets are considered as use values, the productivity ratio cannot be quantified: use values are by definition non-quantitative and noncommensurable. For the TCC to be quantified, assets must be expressed in value and thus money terms. Then the productivity ratio is the price of assets divided by labour units, as in Figure 6 .

The imperialist bloc has a consistently much higher productivity than the dominated bloc and the gap has tendentially widened from $195^{\circ}$ up to the

8 Marx 1967, p. 56o.

9 Marx 1976, p. 773 . 


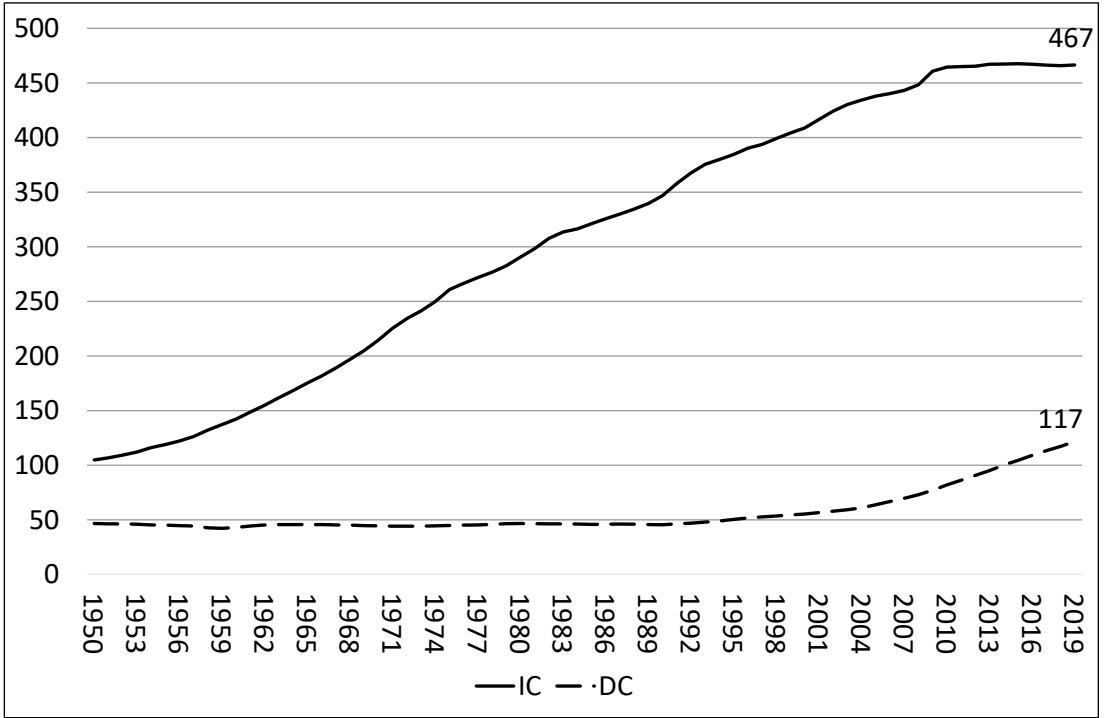

FIGURE 6 Technical composition of capital in the imperialist and dominated blocs, \$bn per employee

SOURCE: PENN WORLD TABLES 10.0, AUTHORS' CALCULATIONS

2007-8 crisis, at which point the TCC has started to rise faster in the dominated bloc. The narrowing of the gap from 2008 has probably to do with the fact that around that time China's investments in fixed new capital (and thus in assets with a higher TCC) started to close the gap with those of the US (see Figure 24 below).

Productivity ratios can be compared both within and between sectors. But they are meaningful only if they indicate profitability. This applies only within sectors where the outputs of capitals with different productivities sell at tendentially the same price. Then the higher productivity capitals sell to other sectors a higher output than that of the lower productive capitals at the same price. The former make higher profits at the expense of the latter. The same does not apply to inter-branch competition. Now it is the rates of profit that are tendentially equalised, not prices. But for the rates of profit to be computed, labour units must be expressed as wages. Then the productivity ratio is the ratio of assets prices (value) to wages. This is the value composition of capital. It follows that the value composition of capital is determined by, but is not equal to, the TCC. Marx calls the value composition of capital as determined by the TCC the organic composition of capital (henceforth, OCC). The TCC and the occ differ because usually changes in the value of assets do not reflect (are not equal to) changes in the mass of assets. The same applies to the value 


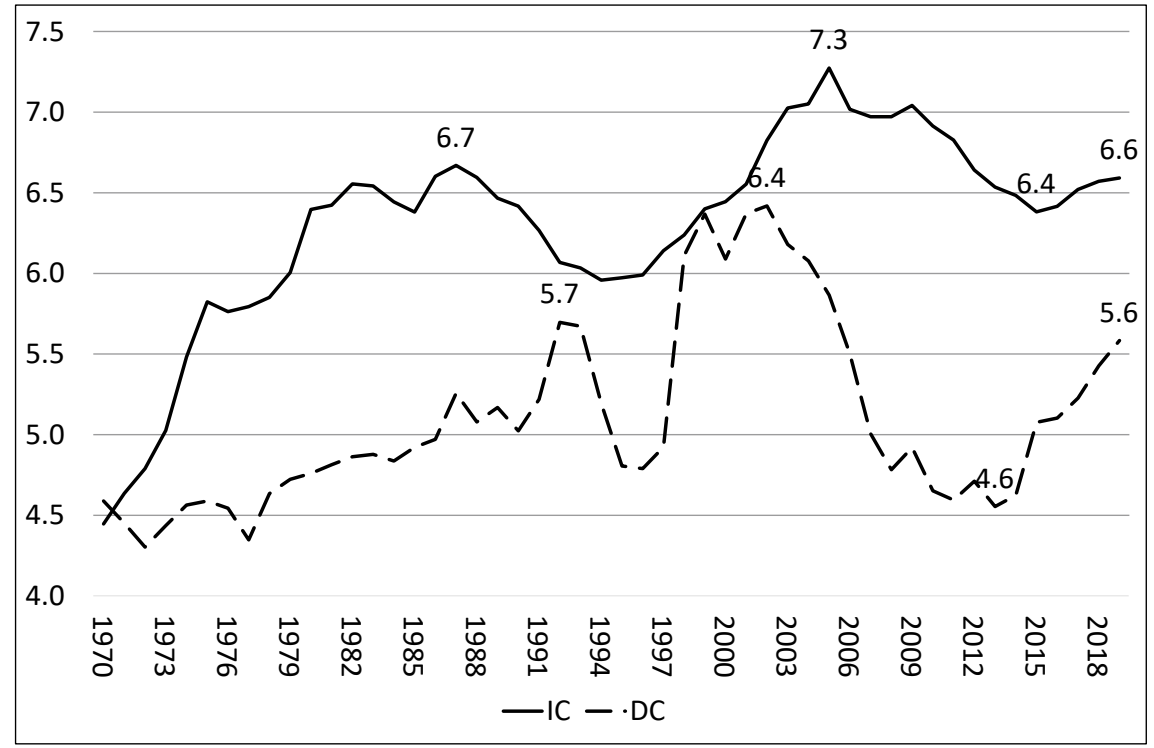

FIGURE 7 The organic composition of capital in the imperialist and dominated blocs SOURCE: PENN WORLD TABLES 10.1, AUTHORS' CALCULATIONS

and quantity of the labour power employed. Nevertheless, the occ, since it is determined by the TCC through the value composition, is the measure of the productivity of labour when different sectors or nations are compared. However, the occ is not a full measure of profitability because, as we shall see below, profitability is determined also by the rate of exploitation.

The ocC of the IC has been consistently higher than that of the DC (Figure 7). Since 1970 , the IC OCC has risen $50 \%$ while the OCC of the DC has risen $20 \%$. Up to the early 20oos, the DC OCC was closing the gap with the IC. But after that there was a significant decline in most Dc countries (excepting China).

Indeed, Figure 8 corrects the widespread opinion that wages rates in the DCs have followed a downward tendential line. Not only did they start to rise from the early 1960 ; they rose faster than IC wage rates from the early 2000 .

\section{Defining Imperialism}

Economic imperialism is in the first instance the appropriation of surplus value by high technology companies from low technology companies in different countries. So, the imperialist countries can be defined as those countries 


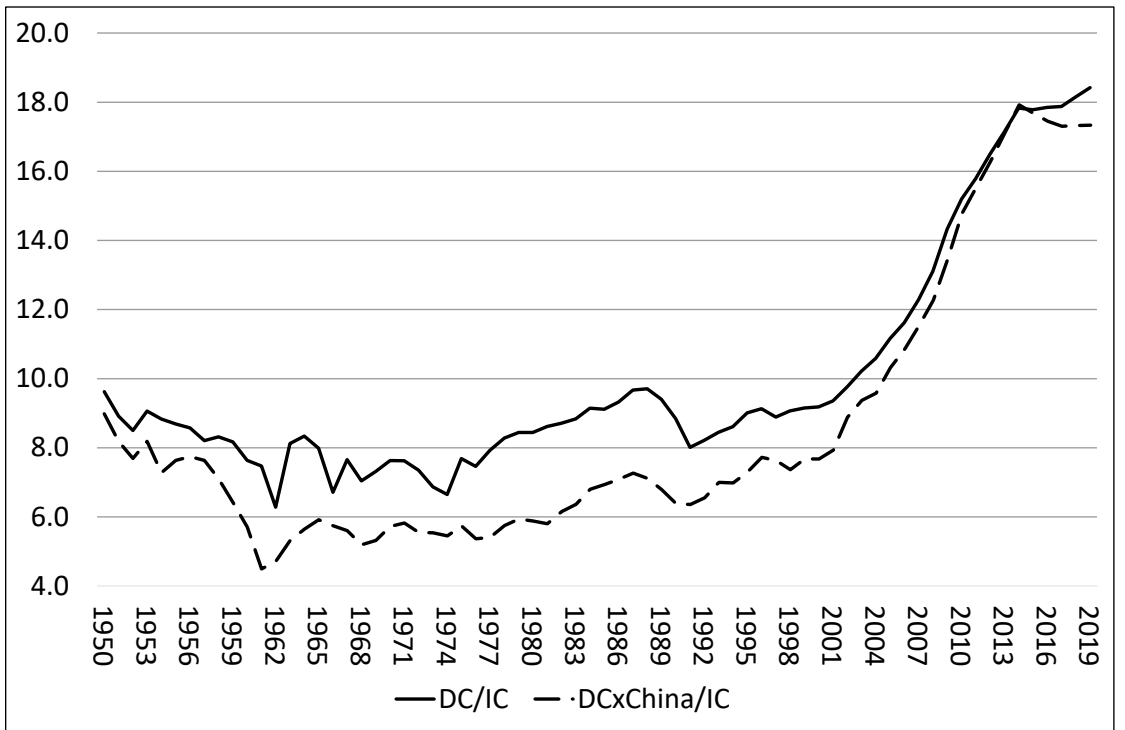

FIGURE 8 Ratio of average wages of dominated bloc to imperialist bloc SOURCE: PENN WORLD TABLES 10.0, AUTHORS' CALCULATIONS

with a persistently higher number of high technology companies and thus with persistently higher national average occ. Their average technological development is persistently higher than the national average of other countries. The latter are thus technologically and economically dominated.

Before we analyse some of the various methods of transfer of surplus value from the dominated economies to the imperialist ones, let us reconsider Lenin's notion of economic imperialism, as summed up in five well-known points from his 1917 work. They are:

1) The concentration of production and capital, developed to such a high stage that it has created monopolies, which play a decisive role in economic life.

2) The merging of bank capital with industrial capital and the creation, on the basis of this 'finance capital', of a 'financial oligarchy'.

3) The export of capital, which has become extremely important, as distinguished from the export of commodities.

4) The formation of international capitalist monopolies, which share the world among themselves.

5) The territorial division of the whole world among the greatest capitalist powers is completed. 
These are characteristic features of modern imperialism defined by Lenin and they are still relevant in 2021. ${ }^{10}$ However, a list of features does not constitute a theory. Lenin's five points should be subsumed under a unifying theoretical frame from which they can be derived. In our view, economic imperialism is a system of international social relations basically founded on long-term technological differentials in which the high technology, high productivity imperialist countries (and thus with higher occs) persistently capture in a variety of ways the surplus value generated in the low-technology and low-Occ dominated countries. Persistent unequal levels of technology are the necessary condition for the persistent appropriation of surplus value. We stress 'basically' because as we shall see below there is another great source of loss of surplus value by the DC, namely their higher rate of exploitation, but which is also determined by the occ differentials.

On this basis, we can define two blocs: the bloc of the imperialist high technology countries (henceforth, HTC) with a persistently higher average OCC and lower average rate of surplus value, and the bloc of the dominated low technology countries (LTC) with a high average rate of surplus value and a persistently lower average occ. The occ differentials and rates of surplus value differentials determine the appropriation of surplus value (as shown in sections 6 and 7 below) by the imperialist countries not as an accidental occurrence or for short-term periods, but for long, multi-decennial periods. Even so, this is not an immutable situation. A country can change from a non-imperialist or dominated status to an imperialist position and vice versa (e.g., Japan in the late nineteenth century). But these changes not only can take decennia to happen. Also, and most important, they do not change the unidirectional flow of surplus value between the two blocs, irrespective of their changing composition.

As pointed out above, within both the LTCs and HTC s, there are low and high technology companies. If the profit rates are equalised among countries, countries with a predominance of high technology companies and average lower rates of exploitation cause a net inflow of surplus value into their country (or bloc). Conversely, countries with a predominance of low technology and average higher rate of exploitation cause a net outflow of surplus value from their countries (or bloc). As Akkermans reports, ' 47 of the 50 [trans-national corporations - G.C. and M.R.] are located in core countries, and 24 in the top core country, the USA. ${ }^{\prime 1}$

\footnotetext{
10 See King 2020 for a detailed, sympathetic treatment of Lenin's theory of imperialism. See also Cheng and Lu 2021.

11 Akkermans 2017, p. 4.
} 
Due to their technological superiority, some countries are hegemonic or leading in the sense that they impose their policies (economic or otherwise) both on other imperialist countries and on countries of the dominated bloc in order to pursue their own interests. This is accepted by other imperialist countries because in fostering their own economic interests, the hegemonic countries foster the interests of the bourgeoisie also in the other countries within that bloc, even if in a contradictory way. Marx spoke of the capitalists as hostile brothers. ${ }^{12}$ The US is the hegemonic country within its bloc and Germany within the European Union. In the EU, one common bond is the euro, which is advantageous both to German and to the other European countries' capitals and disadvantageous for labour. The hegemonic imperialist countries become regional powers and gain spheres of political influence within their blocs.

Economic blocs complicate the flow of value. Value flows among (a) hegemonic and non-hegemonic imperialist countries, (b) among imperialist and dominated countries and (c) among dominated countries. This complex movement results in the flow of value between blocs. Outsourcing complicates this picture further. Companies, usually high technology companies, can commission segments of their production process (from the design, to the production and to the delivery of the finished product) to firms in foreign countries, possibly in other blocs. Due to their higher technology, the outsourcing companies can appropriate surplus value from the foreign suppliers. But this international value-chain does not bring about any substantial change in the nature of imperialism.

Let us now consider the empirical evidence. First the official data. They are not value quantities, yet they are telling. Conforming to our analysis, we would expect the imperialist countries to have net cross-border inflows of income and for non-imperialist countries to have net outflows over time. The IMF defines 'primary income flows' in a country's balance of payments as the net cross-border flows of rent, bank interest and financial-asset returns (as well as workers' remittances). This provides a partial but important picture of the level and direction of 'tribute' flows. ${ }^{13}$

\footnotetext{
12 Marx 1968, p. 29.

13 The IMF defines primary income as 'the net flow of profits, interest and dividends from investments in other countries and net remittance flows from migrant workers'. Since remittances from migrant workers are not transfers of surplus value, these data are an
} 


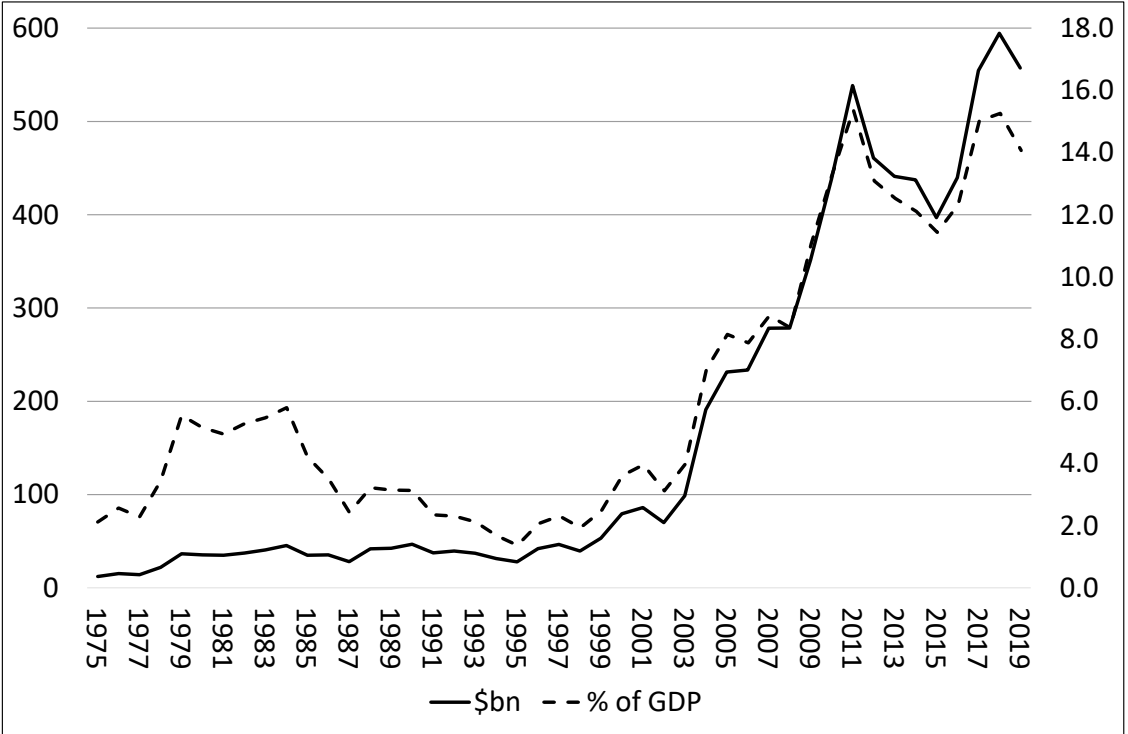

FIGURE 9 Net primary income flows to $\mathrm{G}_{7}$ imperialist countries $\$ b n$, $\%$ of $\mathrm{G}_{7}$ GDP SOURCE: IMF INTERNATIONAL FINANCIAL STATISTICS, AUTHORS' CALCULATIONS, SEE APPENDIX 1

We define the imperialist countries as the $\mathrm{G}_{7}$ and the dominated countries as the rest of the G2o. The imperialist $\mathrm{G}_{7}$ countries run a persistent and rising annual net primary income surplus that reached over half a trillion dollars in 2019, or $14 \%$ of G7 GDP (Figure 9). That's a sizeable contribution to the surplus value of the $\mathrm{G}_{7}$ economies.

In contrast, the DC countries are leaking large amounts of net primary income - up to nearly $\$ 25$ obn a year (Figure 10). Even the strongest of the socalled emerging economies are forced to remain in a dominated role - paying out much more than they receive in primary income. And the trend is worsening.

Another measure of persistent imperialist domination is the stock of foreign investment. The $\mathrm{G}_{7}$ imperialist countries' stock of investment abroad has persistently outstripped such investment by the larger dominated economies. If China were excluded, the gap would be even larger (Figure 11).

Another important source of value appropriation is seigniorage. It is the privilege accruing to the countries whose currency is the international one, most notably the US. The typical case is the US dollar. A substantial quantity

overestimation. Nevertheless, in spite of this overestimation, this is a clear measure of cross-border net surplus value flows. 


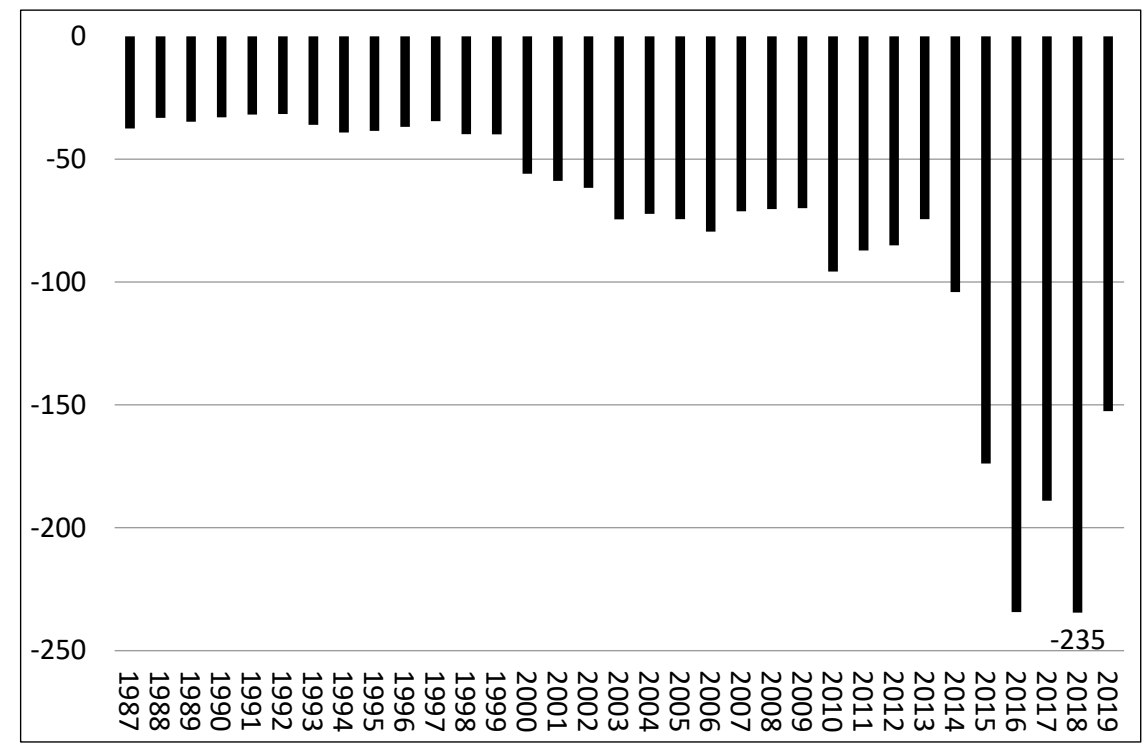

FIGURE 10 Annual net primary outflows from dominated bloc (\$bn) SOURCE: IMF INTERNATIONAL FINANCIAL STATISTICS, AUTHORS' CALCULATIONS, SEE APPENDIX 1

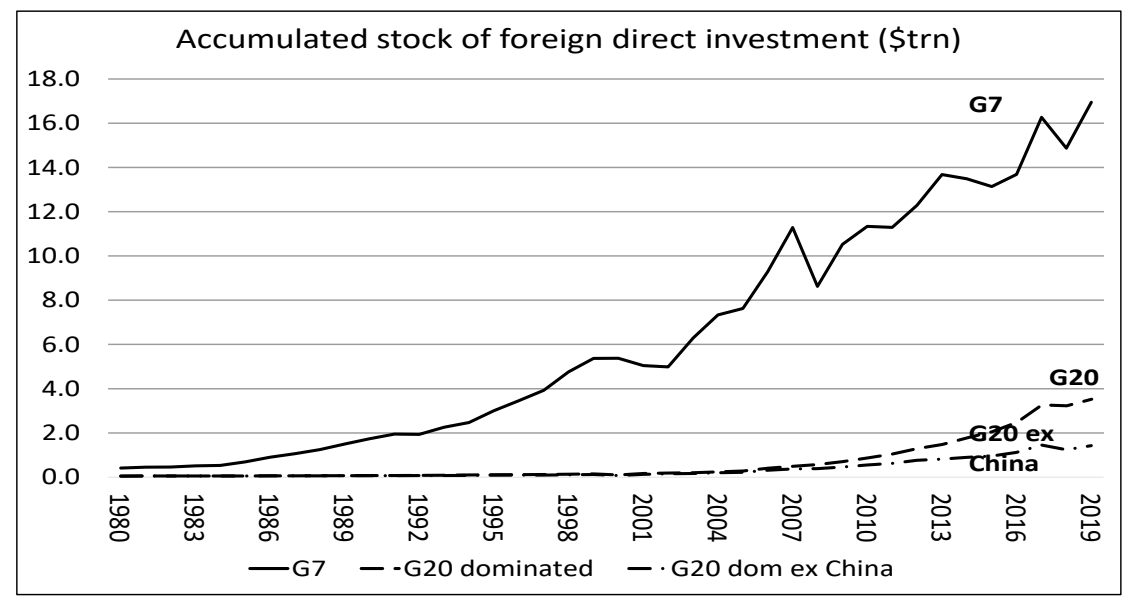

FIGURE 11 Outward foreign direct investment stock (\$trn) SOURCE: UNCTAD, AUTHORS' CALCULATIONS, SEE APPENDIX 1

of US dollars is used by other countries as (a) international reserves, (b) money circulating within those countries and (c) a means of payment on the international markets. US imperialism is able to appropriate surplus value thanks to the international use of the dollar, which has become the international 


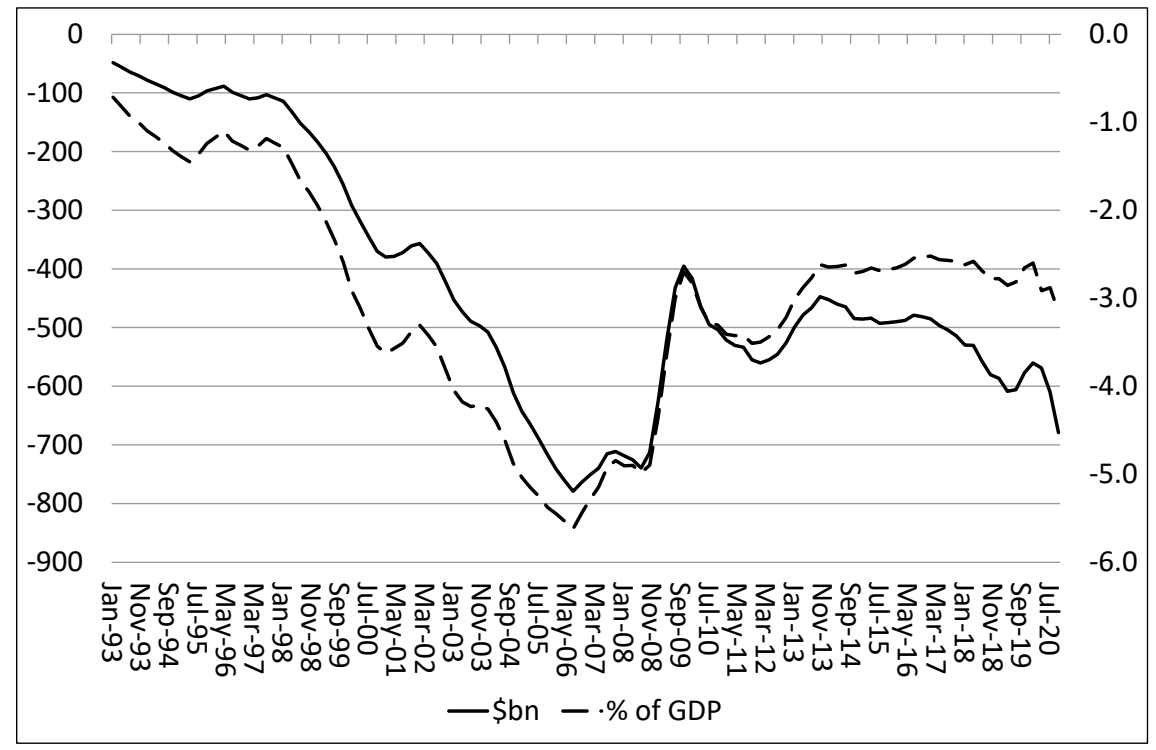

FIGURE 12 US trade balance (USD bn and \% of GDP) SOURCE: FRED, BOPGSTB SERIES

currency of trade, investment, and store of value. ${ }^{14}$ Value (imported foreign commodities) is exchanged for a representation of value (dollars) which is not converted for the imports of US products value. This is international seigniorage (where the state makes a profit from its monopoly in the issuance of a currency).

The US balance of trade is permanently negative. A consistently negative trade balance is something only the country (the US) whose currency is the international currency (the US dollar) can afford. This explains why for about half a century, from the early 1970s, the US trade balance has been constantly negative. From 1993, the deficit rose to a peak deficit of $\$ 770$ billion in 2006, or $5.6 \%$ of GDP, and was still near $\$ 700$ billion in 2020 (Figure 12 ).

This explains why there is a net demand for dollars from the rest of the world. ${ }^{15}$ Dollar net transfers rose to a peak of $\$ 66$ billion in 2014 (Figure 13).

14 Seigniorage is not the only advantage of the dollar as the international currency. For example, by closing off this venue of international money, the US can drastically limit the imports and exports of a nation, thus strangling its economy, as in contemporary Venezuela. More generally, the dollar is the instrument through which the US can control the international financial system. This and other related aspects are not dealt with in this work. For a fuller analysis of the US seigniorage, see Carchedi 2001.

15 This consists of the net sum of withdrawals and deposits of cash at the Federal Reserve, where the ultimate counterparty is located outside the US and covers most commercial banking transfers (see Louwerse 2017). 


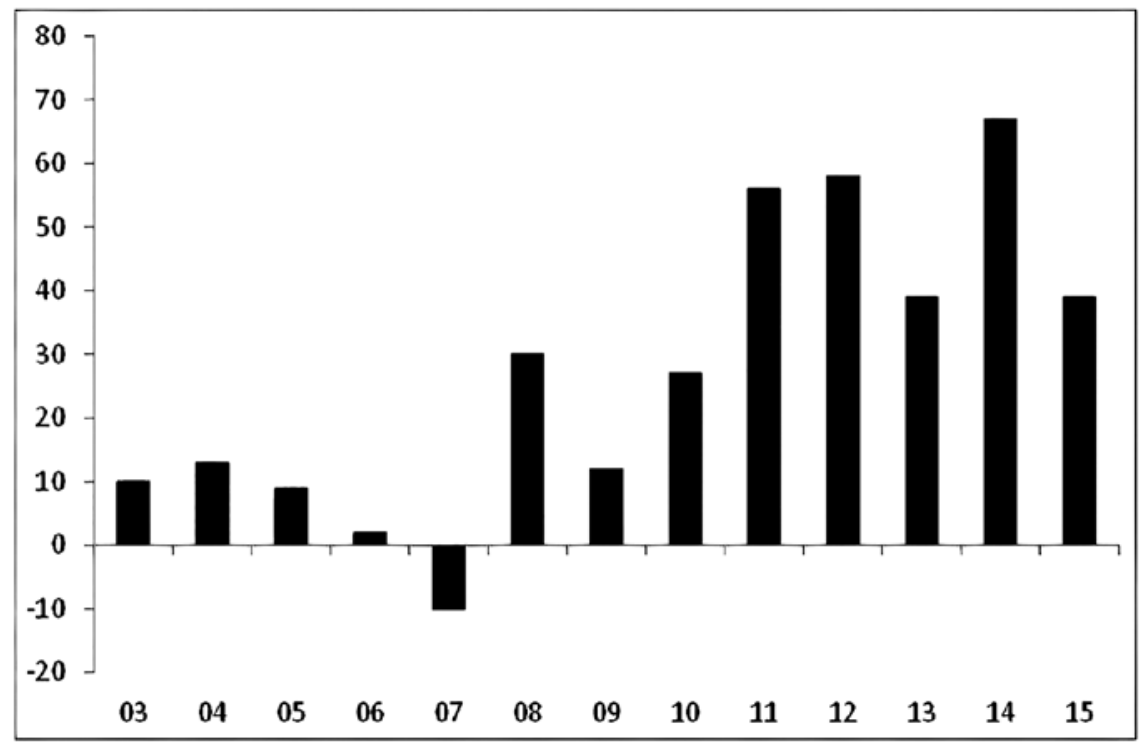

FIGURE 13 Net transfer of US dollar notes to rest of world (\$bn) SOURCE: LOUWERSE 2017

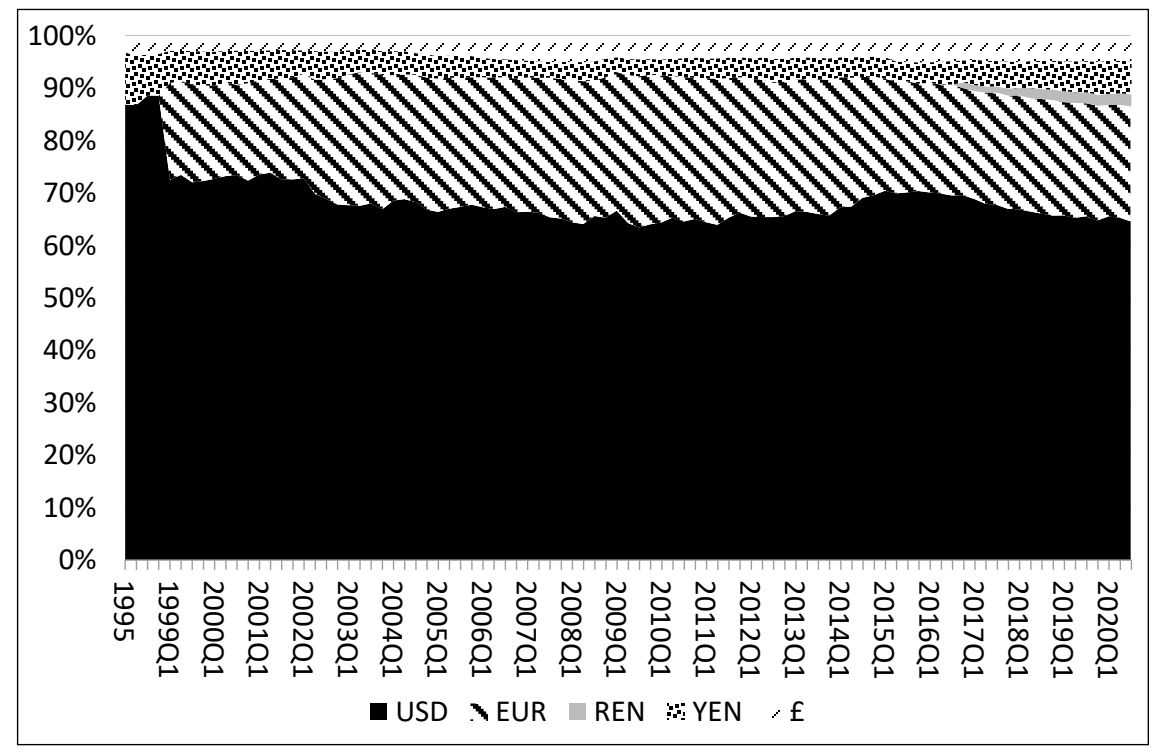

FIGURE 14 Currency share of global FX reserves (\%) SOURCE: IMF COFER (<HTTPS://DATA.IMF.ORG/REGULAR.ASPX?KEY=41175>)

At present the euro is the only possible challenger to the dollar's dominance in seigniorage. But so far that has proved illusory, as more than two-thirds of all FX reserves globally are still held in dollars (Figure 14). 
Whether and when the Chinese renminbi will emerge as a real challenger to the US dollar is a matter of debate. But this is unlikely to happen as long as the US retains its technological superiority together with its absolute military predominance.

\section{Unequal Exchange through Trade}

Unequal exchange (henceforth UE) is another important way that imperialism appropriates international surplus value through international trade. ${ }^{16}$ We rely on Marx's transformation procedure to theorise and compute UE. Its guiding principle is the difference between value before realisation, or unrealised value, and value after realisation, or realised value. The unrealised value is the value contained when the commodity exits the production process before sale. But it is also the value that, having been realised through sale, is sold again either on the national or on the international market. Unrealised value becomes realised each time the commodity is sold because each time it is sold, surplus value is lost/gained. For example, in Table 1.

In a given period, each sector produces a certain output (20oa and 10ob) with a certain value $(120 \mathrm{~A}$ and $14 \mathrm{OB})$. As long as that output is not sold, this is unrealised value. At the end of the period, the two sectors sell their output to each other and realise the value of their products. But this is not the value contained. If that were the case, sector A would not have sufficient purchasing power to buy 10ob and sector B would have an excess of purchasing power. Exchange at value contained would make trade impossible. So, both sectors have to sell at an average value (price) of 130 . This is the production price (henceforth, PP, which is based on the average rate of profit on the capital invested). UE is the surplus value tendentially realised, because it is the difference between the

TABLE 1

$\begin{array}{llllll}\text { Sector A } & 80 \mathrm{OC}+2 \mathrm{OV}+2 \mathrm{OS}=12 \mathrm{O} & \mathrm{PP}=130 & \text { output } 2 \mathrm{OOO} & \mathrm{UE}=+10 & \text { OCC }=4 \\ \text { Sector } \mathrm{B} & 6 \mathrm{OC}+4 \mathrm{OV}+4 \mathrm{OS}=140 & \mathrm{PP}=130 & \text { output } 100 \mathrm{O} & \mathrm{UE}=-10 & \text { OCC }=1.5\end{array}$

Note: Where $\mathrm{C}=$ constant capital; $\mathrm{V}=$ variable capital or value of labour power; $\mathrm{S}=$ surplus value. The sum of these is the value of a sector's production. $\mathrm{PP}=$ prices of production, $\mathrm{UE}=$ the value of the transfer of value between sectors, and OCC $=$ organic composition of capital.

16 We do not review here the various theories of trade. For our purposes, the point is not why countries trade (in a different context we would argue for absolute advantage), but given that they do trade, our point is about the appropriation of surplus value inherent in trade. 
surplus realised on the basis of the tendential equalisation of the profit rates, and the surplus value before realisation (sale). In Table 1, 130 $-120=+10$ for sector $A$ and $130-140=-10$ for sector $B$. The positive or negative UE depends on the height of the occ. The high occ sector (A) gains surplus value from the low OcC sector (B) because the latter produces more surplus value, a part of which, upon redistribution, is gained by the former.

A glance at Table 1 shows that UE is not exploitation. Exploitation is a relation between capital and labour, between surplus value and variable capital. UE is a relation between capitals, namely the appropriation of surplus value when the high occ capitals trade with the low occ capitals.

UE hinges critically on the formation of an average rate of profit (ARP). The formation of the ARP is disputed. The first objection is that the formation of an ARP is supposedly incompatible with monopolistic reality. ${ }^{17}$ But first, monopolies are an exception; what impedes free competition are oligopolies. The argument then is that oligopolies ward off competition through barriers to capital entry because of the sheer size of capital investments needed for the development and application of new technologies. Large investments are thus unavailable to 'free competition' capitals. Note that 'free competition' as used here has nothing to do with its neo-classical meaning; rather, it refers to those sectors of the economy where capitals can compete with each other, but cannot compete with oligopolies because of insurmountable economic barriers. Thus, supposedly, oligopolies prevent the emergence of a one international profit rate, one for the oligopolistic and the other for non-oligopolistic sectors. So, it could be argued that there emerge two ARPs.

The first objection is that oligopolies do engage in technological innovation. This is the opposite of the commonly held view that oligopolies slow down the introduction of innovations. ${ }^{18}$ If a monopoly applies a productivity-increasing new technology, its greater output is exchanged for the output of other monopolies with a lower occ. Then a transfer of value takes place from the latter to the former, just as in the non-monopolistic sectors. Moreover, oligopolies

17 The most prominent authors holding this view are Baran and Sweezy. As Amin 2015 puts it, 'the abolition of competition ... detaches the price system from its basis, the system of values'. The Monthly Review school replaces the notion of surplus value with 'surplus'. This replacement is accepted also by some other writers. See also Duménil and Lèvy 2011, p. 9: 'economically, the purpose of this domination is the extraction of a "surplus" through the imposition of low prices on natural resources and investment abroad, be it portfolio or foreign direct investment.' The substitution of surplus value by 'surplus' shifts the level of analysis back to a pre-Marxian stage. The use of 'monopolies' instead of 'oligopolies' is confusing. There are 'tens of thousands' of oligopolies, i.e. multinational corporations, nowadays. See Cheng and Lu 2021.

As held, for example, by Kalecki; see Sawyer 1988, p. 54 . 
invest in each other's activity (as in conglomerates). An average rate of profit arises within the oligopolistic sector.

So, it could be argued that within a country there are two tendencies towards two national average profit rates, one for each of the two sectors (the oligopolistic and the competitive). Supposedly, this would undermine Marx's theory. But this conclusion changes if countries are considered not in isolation, but as elements of the international economy. For Marx 'on the universal market the integral parts are the individual countries'. The profitability determining the transfer of surplus value necessary for the formation of an international ARP is the profitability of the whole country, the average of the profitability of all capitals within a country, whether monopolistic or not. All capitals, both monopolistic and non-monopolistic, contribute to the inter-country transfer of surplus value and thus to the formation of a national average rate of profit which is an aliquot part of the international ARP. So, from the perspective of the 'universal market', in each country there emerges one ARP. ${ }^{19}$

The second objection to UE questions whether the ARP is a real quantity or simply a statistical average devoid of economic substance. In the latter case, it could not be argued that the transfers of surplus value (UE) computed on the basis of the ARP are real. If empirical observation, it is held, does not show a convergence towards an empirically observable average, then this is proof that there is no such (real) average. Only the scatters are real and ARP is imagined, unreal. ${ }^{20}$

This empiricist view is alien to Marx. Suppose we can observe only capitals with no average profitability. Does the average exist, is it real? The answer depends upon whether we hold a static view or a dynamic one. In the former case, the average can be computed, but it has no real, economic meaning. This seems to be the (implicit) assumption behind the critique. But reality is not static: 'all that is solid melts into air.'21 If reality is considered dynamically, as constantly changing, it is clear that due to capitals' competition, the different rates of profit constantly overtake each other and in so doing create an average (something that becomes more evident the higher the speed of the overtaking), whether that average is represented by a specific capital or not.

\footnotetext{
19 We agree with King 2020, p. 135, that monopolies can charge prices (market prices) above production prices. But production prices should be accounted for to begin with.

20 For example, Cockshott sees a dispersion of rates of profit and concludes that 'The basic problem with Vol III of Capital is that Marx introduces an imagined hypothesis profit rate equalisation which was not backed up by accurate observations.' See https://paulcockshott.wordpress.com/2020/o5/11/equalisation-of-rate-of-profit-or-equalisation -of-rate-of-surplus-value/. 
The international UE is an application of the procedure above to the international economy. But there are differences. Now countries replace sectors. Their output must be sold on the international market. The value (GDP) is realised national value because it is the sum of the surplus value realised by all the sectors in each country through the reciprocal sale of their products. But it is also the unrealised international surplus value as long as it is not sold on the international market. At the moment of sale on the international market, the surplus value contained in the GDP is redistributed into an international ARP. Then the international production prices are the values tendentially realised due to the international equalisation of the national rates of profit. The difference between the international production prices (international realised surplus value) and the national GDPs (internationally unrealised surplus value) is the international UE. There is nothing mysterious about the GDP being the realised national value, but unrealised international value. It is a matter of the scope of the analysis, i.e., whether the scope is intra- or international.

UE should not be confused with the deficit or surplus of the trade balance. In Table 1 above, let us substitute sector A with the US and sector B with China. In the case of narrow UE, both the US and China export at a price of 130 and import at a price of 130. The balance of trade is in equilibrium. Yet the US books a positive $U E$ and China a negative one. This result is of great significance for the relation between these two economic giants, as we shall see in section 9 below.

There are other features specific to the formation of the international UE. To begin with, the effects of the rate of surplus value on the production and redistribution of international surplus value. Within a nation it can be assumed that the sectors' rates of exploitation are equalised into an average rate. But this assumption should be modified if nations are compared. Each nation has its own rate of exploitation, i.e., surplus value divided by variable capital. In symbols, $S^{\prime}=S / V$. We call this the unadjusted $S^{\prime}$. We hold that $S^{\prime}$ should be adjusted by UE.

The reason is as follows. Take a negative UE. It is surplus value lost by national capital through trade. Thus, the surplus value extracted from labour is $S+U E$, the surplus value remaining to the national capitals plus the surplus value lost to foreign capital. Alternatively, if UE is positive, UE must be subtracted from surplus value accruing to that capital to find the surplus value before international appropriation, i.e., extracted from the national labour force. So, the surplus value actually expropriated from labour is $\mathrm{S} \pm \mathrm{UE}$ and the adjusted rate of surplus value is $S^{\prime}=(\mathrm{S} \pm \mathrm{UE}) / \mathrm{V}$. It follows that exploitation is underestimated in the countries with negative UE (the DC) and overestimated in the countries with a positive UE (the IC). To assess the relative weight of the adjusted S' versus that of the OCC in the formation of UE, we use the principle that if the OCC 
differentials are greater than the $S^{\prime}$ differentials, the former contribute more to the flow of value, and vice versa.

Finally, we calculate UE in two ways, which we distinguish as UE based on narrow bilateral trade (narrow UE for short) and UE based on broad bilateral trade (broad $U E$ ). In the narrow $U E$, the assumption is that two countries trade only with each other. This assumption is unrealistic, but it is useful if we focus only on the relation between two countries. In the broad UE, we apply the more realistic assumption that the two countries trade also with all other countries. Appendix 2 shows how UE is computed in each of these two cases.

Let us now consider some alternative views of UE. Cockshott holds that UE is not a redistribution of surplus value through international trade, but the creation of surplus value. ${ }^{22}$ For example: 'A ton of US maize contains a lot less labour than a ton of Mexican maize. But once imported to Mexico the US maize sells at the same price under Nafta as the domestic variety'. The effect is that 'one hour by a US farmer creates more value than one hour by a Mexican one'. Not so, in our view. If a ton of US maize requires less labour than a ton of Mexican maize, the quantity of US labour that has gone into a ton of maize does not change just because it is exported. Once exported, the US maize counts as more value than the value required for its production because - if the US and the Mexican maize are sold at the same price - the US agricultural capitalist appropriates through UE a share of the surplus value generated in the production of the Mexican maize.

Kohler identifies UE in the exchange-rate mechanism and measures it as the difference between the GDP valued at PPP (purchasing power parity) and at current exchange rates. ${ }^{23}$ In the PPP approach, the same basket of goods is identified in all countries. They can be aggregated in the goods making up the GDP. Consider a limited example: the US and Colombia. One computes how many commodities US $\$ 1$ can buy in the US and how many pesos are needed to buy the same commodities produced in Colombia. Suppose an American spends $\$ 1$ on a bundle of commodities A produced in the US. If a Colombian spends 4.64 pesos to purchase the same A in Colombia, the PPP ratio is $\$ 1=$ 4.64 pesos. Suppose now that the actual exchange rate (ER) is $\$ 1=5.5^{2}$ pesos. An American who exchanges $\$ 1$ for $5.5^{2}$ pesos and spends them in Colombia can purchase more Colombian commodities. The measure of this difference is the exchange rate deviation, $\mathrm{d}$, which is ER/PPP. In the example above, $\mathrm{d}=$ $5 \cdot 52 / 4.64=1.23$. Then, $\mathrm{T}=\mathrm{X}^{*} \mathrm{~d}-\mathrm{X}$ where $\mathrm{T}$ is unequal exchange and $\mathrm{X}$ is the volume of exports from a low-wage country to high-wage countries.

22 Cockshott 2019.

23 Kohler 1998. 
Let us consider Kohler's T more closely. In the example above, if XR is $\$ 1=$ pesos 4.64, in terms of Kohler's approach there is equal exchange. If the peso is devalued to $\$ 1=$ pesos 9.28 , the holder of $\$ 1$ can purchase $2 \mathrm{~A}$ in Colombia. One A is lost by Colombia and gained by the US. This is unequal exchange.

The first thing to be remarked is that $\mathrm{T}$ is a measure of value without a theory. If XR does not move towards the PPP, then its movement is random. If it does move towards the PPP, then no reason is provided for this movement. In both cases there is no theory of T. But even as a theoretically empty way to measure $\mathrm{UE}, \mathrm{T}$ fails. The reason is that $\mathrm{T}$ is due to prices in the LTC being lower than in the HTC. However, prices delinked from values do not indicate positive or negative UE. In the example above, the exchange ratio $\$ 1$ = pesos 4.64 would indicate equal exchange. But if $\$ 1$ represents 1 hour of labour in the US and pesos 4.64 represents $1 / 2$ hours in Colombia and if the XR is $\$ 1=$ pesos 4.64 , then there is equal exchange in terms of prices but negative UE for the US in terms of value. Nothing can be said of the UE because of the missing link between prices and values.

One could choose to disregard the value dimension. Then money prices represent use values. However, use values are by definition different and thus incommensurable. If money represents use value, it cannot make them equal and commensurable. Quantities must be homogeneous before money can express that homogeneity and commensurability. The choice of the labour theory of value is not a matter of preference. It is simply a matter of formal logic. ${ }^{24}$

Emmanuel's UE rests on the thesis that, 'The capitals invested can themselves be equalised, yet the transfer of value from one country to another will take place nonetheless.' ${ }^{25}$ This transfer of value, or UE, is caused by 'the institutionally determined wage levels ("rates of surplus value") in the presence of an internationally equalised rate of profit'. ${ }^{26}$ In the discussion that followed the publication of Emmanuel's works, it became customary to distinguish between 'broad UE' - due to differences in the OCC - and 'narrow UE' - due to differences in wages and rates of exploitation. ${ }^{27}$ Supposedly, the equalisation of the rates of profit occurs on the basis of the different occ, and different wage levels modify it.

24 This raises serious doubts about the validity of the estimates of UE based on Kohler's T, as for example in Hickel, Sullivan and Zoomkawala 2021.

25 Emmanuel 1972, p. 61.

26 Emmanuel 1972, p. 64.

27 We too speak of broad and narrow UE, but from a different perspective (see above). 
TABLE 2 Emmanuel UE

\begin{tabular}{llllllllll}
\hline country & K & c & V & S & V & PP & UE & RSV & OCC \\
\hline A & 240 & 50 & 100 & 20 & 170 & 210 & +40 & $20 \%$ & 2.4 \\
B & 240 & 50 & 20 & 100 & 170 & 130 & -40 & $500 \%$ & 12.0 \\
\hline
\end{tabular}

Emmanuel submits the following example as in Table 2, where $\mathrm{K}$ is the total capital invested and $\mathrm{c}$ is the constant capital (value) actually used.

B has a higher OCC (12.0) than A (2.4). So B should gain surplus value from A. Yet it has a negative UE $(-40)$. This seems to contradict Marx's thesis that UE is determined by different occ.

Emmanuel makes a methodological error. Marx presupposes the equality of the RSv because he considers different sectors within a country. But this hypothesis should be dropped within the context of the international economy, as Marx himself states. Then the different wage levels must enter the equalisation of the profit rates together with the different occ. They do not modify the ARP; they contribute to its formation. Country B loses surplus value even if its Occ is higher because Marx's assumption has been expanded to the case in which the RSV s are different. If the RSvs are equalised, the low occ country loses and the high occ country gains surplus value, as in Marx. ${ }^{28}$ B's higher productivity is not sufficient for it to gain a higher profitability. ${ }^{29}$ Profitability depends on both productivity and exploitation. Then the question is which one weighs more in determining UE. In Table 2, B's RSV is higher (500\%) than A's $(20 \%)$. So B loses surplus value to A on this account while gaining surplus value to its higher occ. On balance, what B loses due to its higher RSV is more than what it gains due to its higher occ. Indeed, the ratio between the two RSV is 25 , which is higher than the ratio between the two occ, which is 5 . Wage and surplus-value differentials do not contradict Marx's equalisation procedure, they complement it.

Another way to compute UE is through the Input-Output analysis. These tables have the advantage of identifying which sectors within different countries are responsible for a positive or a negative transfer of value. From this perspective, this method is not alternative but complementary to ours. However,

28 The reader can easily check that in this case A would lose -18 and B would gain that much, conforming to Marx.

29 We leave aside the question as to whether wages are the independent variable, as Emmanuel holds and as Bettelheim disputes (see Bettelheim, p. 288, in Emmanuel 1972). 
the input-output tables do not compute prices on the basis of the equalisation of the profit rates and thus of the production prices derived from such an equalisation. Yet this is an essential step before the market prices can be accounted for. Instead, these tables depict and analyse the dependence of one industry or nation on the others through a set of linear equations connecting market prices only.

Within this framework, there is no room for tendential values. And there is no room for time either: the assets as output of one period are deemed to be the same as the assets as input of the same period. We hold that this simultaneist view is alien to Marx as well as to reality. However, in spite of this, several authors using the input-output tables have reached many important conclusions broadly consistent with ours. ${ }^{30}$

On a different line, Gibson holds that the labour theory of value has nothing to do with UE. ${ }^{31}$ The author mentions two reasons. First the IC can sell their commodities below their value. But 'Buy cheap, sell dear' has nothing to do with UE. Second, 'a transfer of value ... is meaningless if commodities are exchanged at their prices of production'. But UE originates just because commodities are exchanged at their production prices.

Finally, Norfield challenges that different occ s are key to understanding flows of value: 'how corporations and countries appropriate surplus value may have little to do with their " $\mathrm{C}+\mathrm{V}$ " investment or production! It may have more to do with their commercial and financial power in the world economy! ... It is more important to analyse forms taken by capitalist exploitation today than to waste time refining $\mathrm{C}, \mathrm{V}, \mathrm{S}$ data. ${ }^{32}$ We show that both the extremely high levels of exploitation in the DC and the commercial and financial power of the IC are ultimately determined by the occ differentials as the expression of technological superiority.

\section{7}

\section{Measuring Unequal Exchange}

We have argued that international surplus value flows from the DC to the IC because the former generally have a higher rate of surplus value and lower occ. This section presents empirical evidence to support this thesis. ${ }^{33}$

$30 \quad$ Tsaliki, Paraskevopoulou and Tsoulfidis 2018; Ricci 2018; Herrera, Long, Feng and Li 2020; Nakajima and Izumi 1995; Mavroudeas and Seretis 2018.

31 Gibson 1980.

32 Norfield 2019.

33 We explain in detail our sources and the methods we adopt in order to do this in Appendix 2. 
We start with UE between the IC and the DC. In Figure 15, we base our results on eight economies in the G2O as the imperialist bloc (IC) and 11 economies in the $\mathrm{G} 2 \mathrm{O}$ as the dominated bloc. ${ }^{34}$ Although this does not cover all imperialist and dominated economies, it does cover the most important ones and so provides robust support for trends.

First, we measure the UE transfers of value against the GDP. We find that the annual transfer of surplus value to the IC bloc averaged about $1 \%$ of IC GDP a year while the annual transfer of surplus value from the DC bloc averaged also about $1 \%$ of DC GDP (Figure 15 ). ${ }^{35}$ This may seem small, but we are only calculating for eleven DC s. No doubt the results would show a larger transfer with more DCs included. Moreover, this is an annual transfer and the cumulative transfer over 70 years is thus considerable.

The transfer of surplus value measured against annual profits from exports is much more significant than against GDP. The positive transfer of surplus value to the IC is equivalent to over $40 \%$ of annual IC export profits and the negative transfer of surplus value from the DC is equivalent to over $20 \%$ of annual DC export profits (Figure 16).

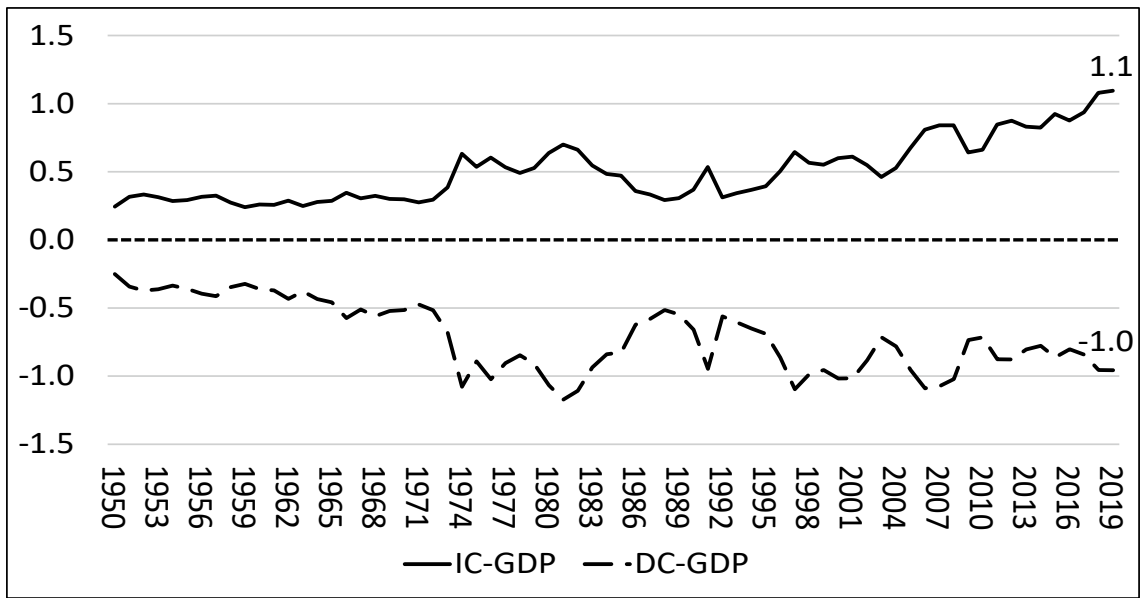

FIGURE 15 Transfer of surplus value for the IC and DC as \% of GDP s SOURCE: PENN WORLD TABLES 10.0, APPENDIX 2

34 The missing economy in the $\mathrm{G} 2 \mathrm{O}$ is the $\mathrm{EU}$ as a whole.

35 This is our measure of 'narrow' UE of trade between two blocs without reference to trade outside the blocs. Given that the G2O constitutes over $70 \%$ of global GDP, there is no necessity to consider the broad UE measure in this case. 


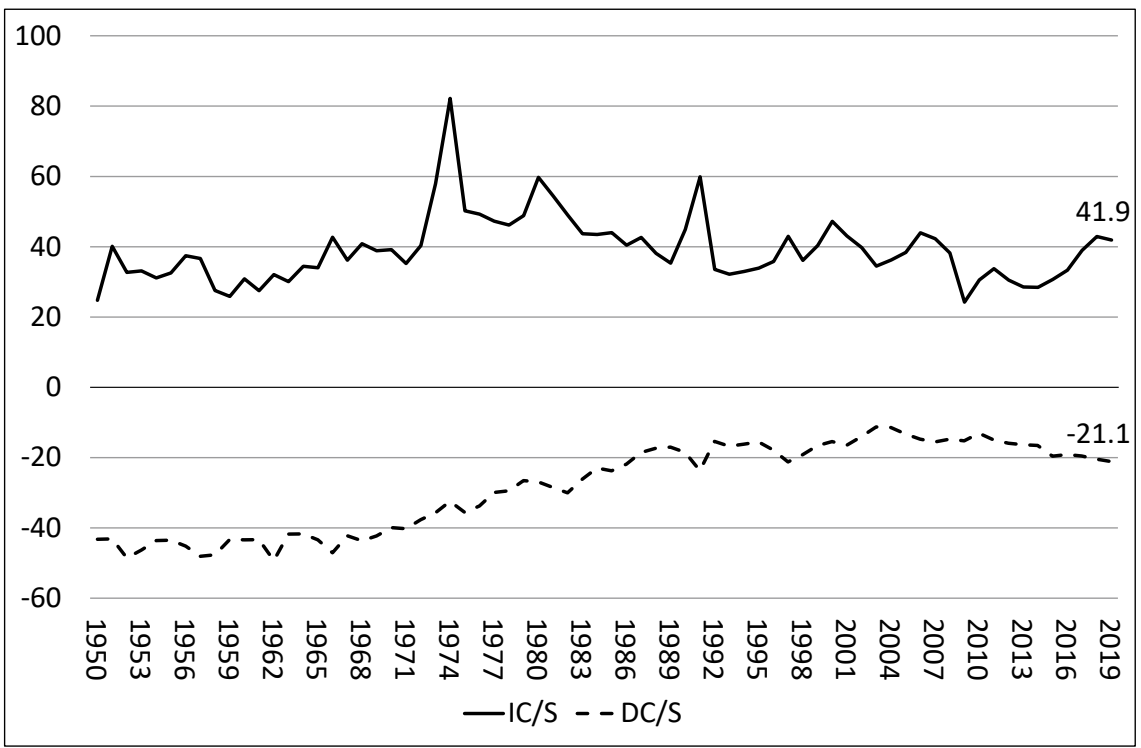

FIGURE 16 UE transfer between the IC and DC as share of annual export profits (\%) SOURCE: PENN WORLD TABLES 10.0, APPENDIX 2

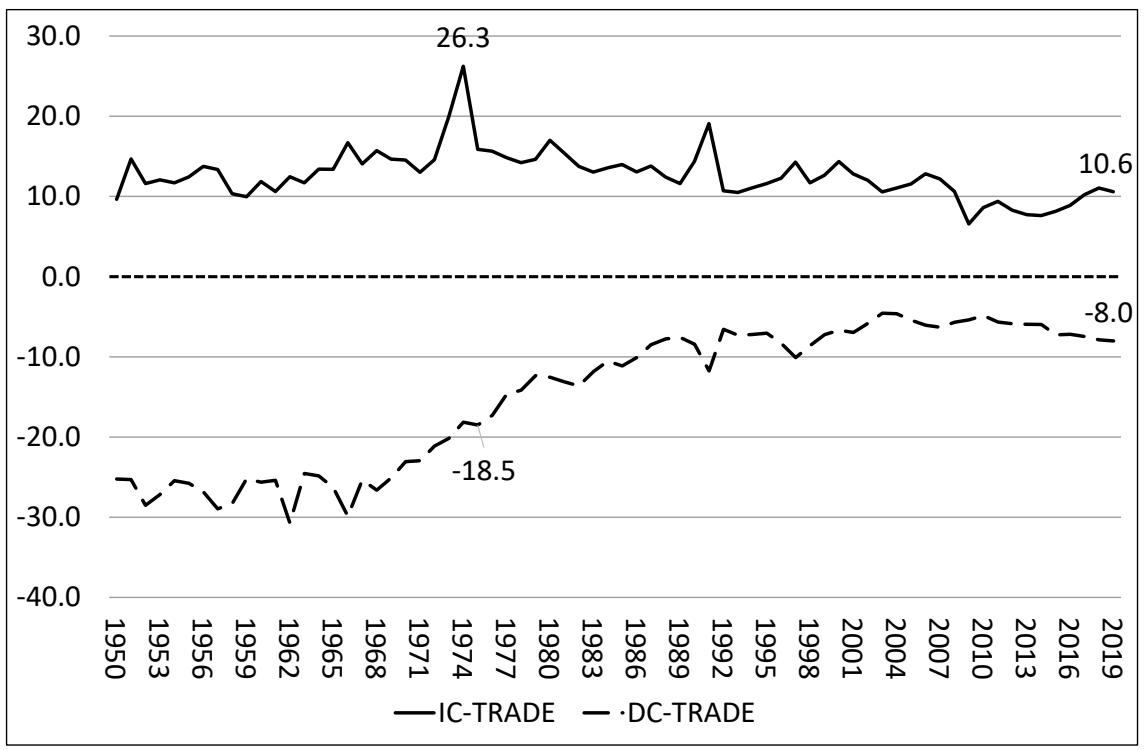

FIGURE 17 UE transfer between IC and DC as share of annual bilateral exports (\%) SOURCE: PENN WORLD TABLES 10.0, APPENDIX 2

The UE transfer is also sizeable when measured against each bloc's bilateral export trade (Figure 17). 
We can also measure the contribution of the differential of the occ s and of the differential of the rate of surplus value between the IC and DC blocs. We find that an average of $6 \circ \%$ of the surplus value transfer since 1970 has been due to the occ differential and $40 \%$ due to the rate of surplus value differential (Figure 18).

In Appendix 2, we also look at the surplus value transfers between the US and selected countries, i.e., China, Mexico and the UK. And we also consider the surplus value transfer between the IC and China. And we consider the surplus value transfer from both the 'narrow' and the 'broad' definitions, as explained in Appendix 2. In Table 3 below we summarise the results for the transfer of surplus value between the US and Mexico and the US and the UK as share of annual exports.

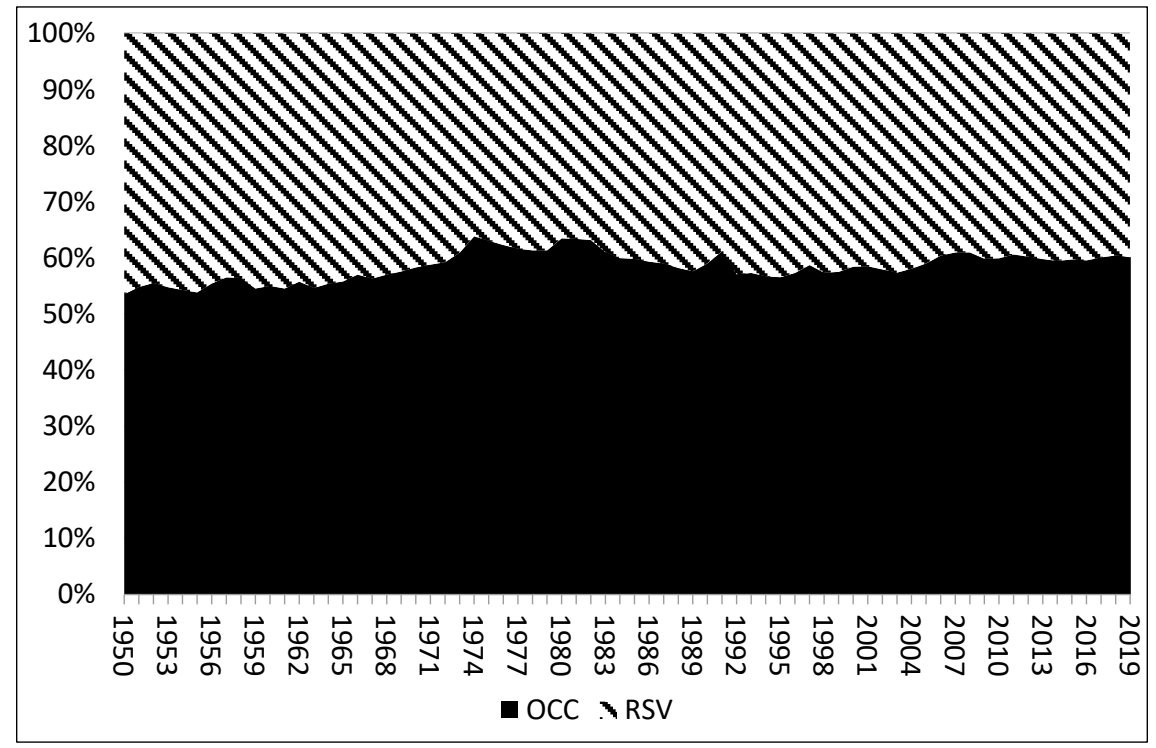

FIGURE 18 Relative contribution of OCC and RSV to value transfer between IC and DC (\%) SOURCE: PENN WORLD TABLES 10.0, APPENDIX 2

TABLE 3 Average transfer of value (\% of trade) $-1950-2019$

Narrow UE Broad UE

\begin{tabular}{lrlrlrlr}
\hline US-Mexico & 16.0 & Mexico-US & -15.3 & US-Mexico & 21.2 & Mexico-US & -11.3 \\
US-UK & 3.0 & UK-US & -3.4 & US-UK & 6.1 & UK-US & -0.4 \\
\hline
\end{tabular}


The transfer of surplus value from Mexico to the US is much larger as a share of trade than it is between the UK and the US. That is because the occs of the UK and the US are similar.

To sum up, the major cause of UE is the technological superiority of the imperialist countries and the higher rate of surplus value in the dominated countries. Differences in the rates of surplus value between imperialist and dominated countries are significant, but are a consequence of productivity differentials and play a lesser role. Exclusive emphasis on only one of these two factors is one-sided and as such unsuited to explain UE. In the final analysis, the question of which factor contributes more to $\mathrm{UE}$ is dependent on whether the rates of surplus value differentials are greater or smaller than the organic compositions of capital differentials.

\section{$8 \quad$ Unequal Exchange and Exchange Rates}

Exchange rate movements are another source of surplus value appropriation specific to capitalism. In conventional economics there are basically three theories of exchange rates. The balance of payments theory states that if a country's balance of payments has a surplus, the greater demand for its currency causes its appreciation, and vice versa for a deficit. Exchange rates tend towards the point at which the balance of payments is in equilibrium. The purchasing power parity theory holds that exchange rates tend towards the level at which the purchasing power between two countries is equalised. This is the quantities of the countries' currencies that can buy the same basket of goods in both countries. At that point, exchange rates have reached their equilibrium level. The monetary theory postulates that the exchange rates are determined through the balancing of the total demand and supply of the national currency in each country.

These and other similar theories have been subjected to criticism on a number of grounds. They will not be reviewed here because, whatever their differences, they share a common matrix, the fundamental, empirically unproven, internally inconsistent and ideologically-laden postulate that the capitalist economy tends towards equilibrium, however defined. Yet it is for all to see, except for equilibrium economics, that the capitalist economy is a non-equilibrium system. It tends not to equilibrium, but to crises.

Besides conventional economics' theories of UE, there are also Marxist studies. In the 1970s, a number of authors ${ }^{36}$ produced important studies, which,

$36 \quad$ Altvater, Blanke and Neusiiss 1971; Busch, Scholler and Seelow 1971. 
however, have been superseded on account of their being based on the assumption of capital immobility. More recently, Shaikh and Antonopoulos have submitted that 'the sustainable real exchange rate is that which corresponds to the relative competitive position of a nation, as measured by its relative real unit labor costs' ${ }^{37}$ The advantage of this approach is that it relates competitivity to the exchange rates (henceforth, XR). Broadly speaking, the authors reckon that the DC improve their profitability (competitive position) by lowering their labour costs while the IC do that by raising their productivity. This is correct. But the DC lower their wage levels because of their lower productivity. So the exchange rates should 'correspond' to productivity differentials rather than to wage differentials.

Let us elaborate. As seen above, the HTC gain surplus value from the LTC through UE in international trade. If the exporting country (the DC) has a lower OCC, the higher the volume of exports, the greater the loss of surplus value. The LTC's rate of profit falls. As a counter-measure, the DC can reduce wages and increase exploitation.

An alternative is devaluation. Consider changes in the exchange rate (XR) between the US $\$$ and the Mexican peso (MXN). In 1991 it was $\$ 1=$ MXN 2.o. By 2021 it was $\$ 1=$ MXN 25.0. ${ }^{38}$ In 2021, US-Mexico trade increased to the point that the US became Mexico's major trading partner. Exports to and imports from the US now account for $75 \%$ of Mexico's total foreign trade. At the same time, the US appropriated a vast and increasing share of Mexican profits generated in the export sectors, as shown in Table 3 above.

More specifically, if the Mexican exporters must pay MXN 25.0 instead of MXN 2.0 for $\$$, it would seem that the Mexican export sector loses surplus value to the US import sector, i.e., that the loss is borne by Mexican exporters. Actually, after devaluation, with $\$ 1$ the US importers can purchase many more Mexican commodities, both means of production and of consumption. So, it is Mexican capitalists and labour as a whole that lose the value incorporated in the lost use values. The rate of profit in Mexico falls. As for the Mexican exporters, with the revalued $\$ 1$ they can buy MXN 25.0 (instead of MXN 2) worth of Mexican goods. So their MXN rate of profit rises, while that of the economy as a whole falls. Fewer Mexican commodities are available both to Mexican capital and to Mexican labour. Devaluation impoverishes labour and weakens the capital of the LTC, but enriches the exporting capitals. The export sectors

37 Shaikh and Antonopoulos 2013, p. 210.

$3^{8}$ Source: $<$ fxtop.com $>$. 
claim a greater part of a shrinking quantity of means of consumption and production. This can contribute to inflation in Mexico. ${ }^{39}$

This said, do the XR move randomly or do they tend towards a definite point? We have discarded the prevalent theories of exchange rates because they are rooted in equilibrium assumptions. The perspective of the value theory is different. In the perception of the monetary authorities (i.e. of the capitalists), devaluation is meant to increase exports and to correct the deficit in the balance of trade. So it would seem that the XR tends towards the point at which the deficit is corrected. At that point, the movement in the XR would stop (the equilibrium perspective). In reality, the XR are determined by the export sectors' and (indirectly) by a country's productivity (TCC). If the LTC's productivity falls relative to that in the HTC, less use values are produced and thus exported per unit of capital invested, and so the balance of trade deteriorates. The higher the ratio of the TCC in the HTC relative to the TCC in the LTC is, the greater the devaluation in the LTC.

But this is not an equilibrium position. Firstly, even if a position of equilibrium could be reached (by chance), the LTC would suffer a negative UE. Secondly, the xr does not tend towards the level at which the balance of trade is in equilibrium. The XR does not stop when the balance of trade is in equilibrium, but follows the reciprocal movement of the TCC. It could be said that the $\mathrm{XR}$ tend to the point at which the two TCC are equal. But this cannot happen under imperialism.

To illustrate our argument, we have chosen three examples: the US vs. (a) a dominated country, Mexico, (b) an imperialist country, Germany and (c) China. The correlation between the relative TCC s and XR is very strong in all three cases.

As the TCC ratio US-Mex rises, more MXP is needed against the USD (Figure 19).

In the case of the US and Germany, prior to the formation of the euro, the US TCC falls relative to Germany after 1971, and the USD-DM XR also falls (Figure 20). Again the correlation is high at 0.78 .

In the US-China case, the US-China TCC ratio falls, as China catches up in technology and the USD-CNY XR also depreciates. Again, the correlation is very high at 0.90 .

Two points follow. First, the bigger the ratio of the two TCC s, the greater the need by the LTC to devalue, the greater the appropriation of surplus value by the Hтс. Second, the above focuses on the appropriation of surplus value by a HTC from a LTC. But that surplus value is partly produced by the LTC and 


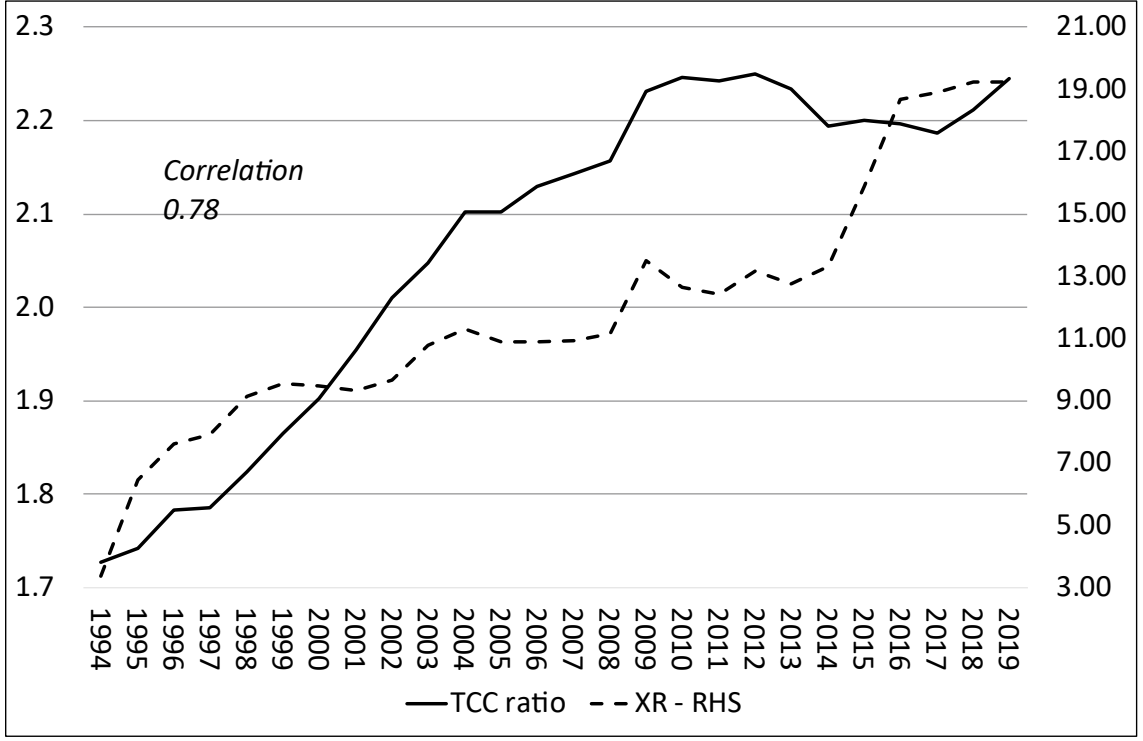

FIGURE 19 US and Mexico TCC $s$ and the exchange rate, 1994-2019 SOURCE: PENN WORLD TABLES 10.0 AND FRED DEXMXUS

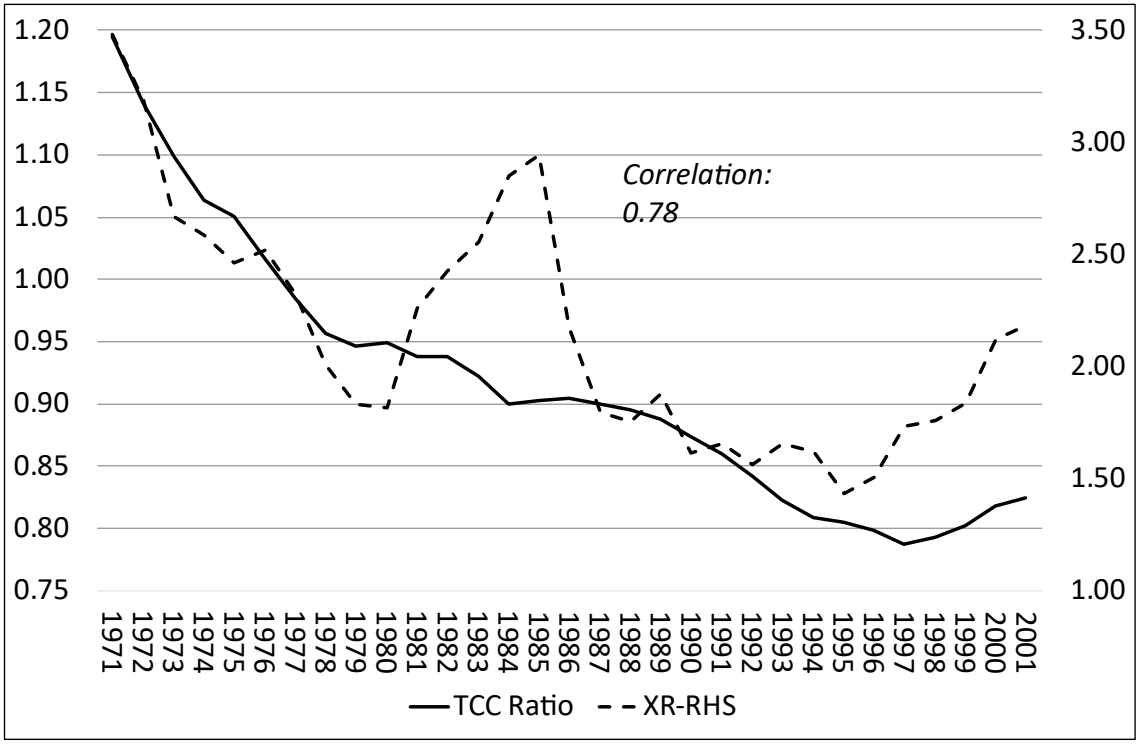

FIGURE 20 US and Germany TCC $s$ and XR, 1971-2001

SOURCE: PENN WORLD TABLES 10.0 AND FRED EXGEUS

partly appropriated by the LTC if it revalues vis-à-vis a third country. So the international flows of value due to the movements in the XR hide the intricacies of reciprocal gains and losses. 


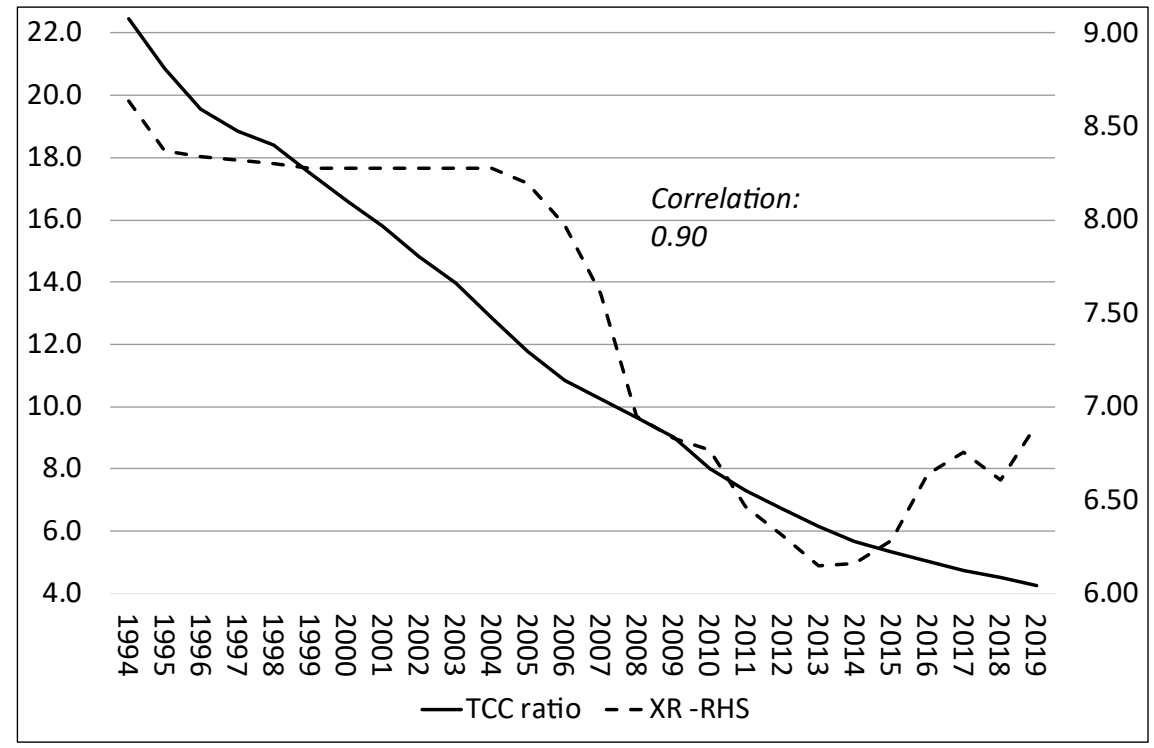

FIGURE 21 US and China TCC $s$ and XR, 1994-2019

SOURCE: PENN WORLD TABLES 10.0 AND FRED

As an example, consider Taiwan. From 1990 to 2021, the TwD (Taiwan dollar) appreciated consistently against the Turkish Lira. So Taiwan gained surplus value from Turkey. At the same time, the TWD depreciated relative to the USD. So the US gained surplus value from Taiwan, which in its turn gained surplus value from Turkey. So a share of the surplus value (and thus output) appropriated by the US from Taiwan comes from the Taiwanese workers and another share comes from the Turkish workers.

\section{$9 \quad$ China and Imperialism}

The relation between these two economic giants, the US and China, has become so important in the twenty-first century that it requires a section of its own. The critical question then arises: is China an imperialist nation? To answer this question, we consider the transfer of surplus value from China to the Ic. We find that there is a clear transfer of surplus value from China to the IC bloc, averaging $5^{-10} \%$ of China's GDP since the 199os. The IC has gained an average of $1 \%$ of IC GDP from trade with China (Figure 22).

As China's exports to the imperialist bloc have expanded, the negative transfer of surplus value has risen to reach over $13 \%$ of China's export profits (Figure 23). 


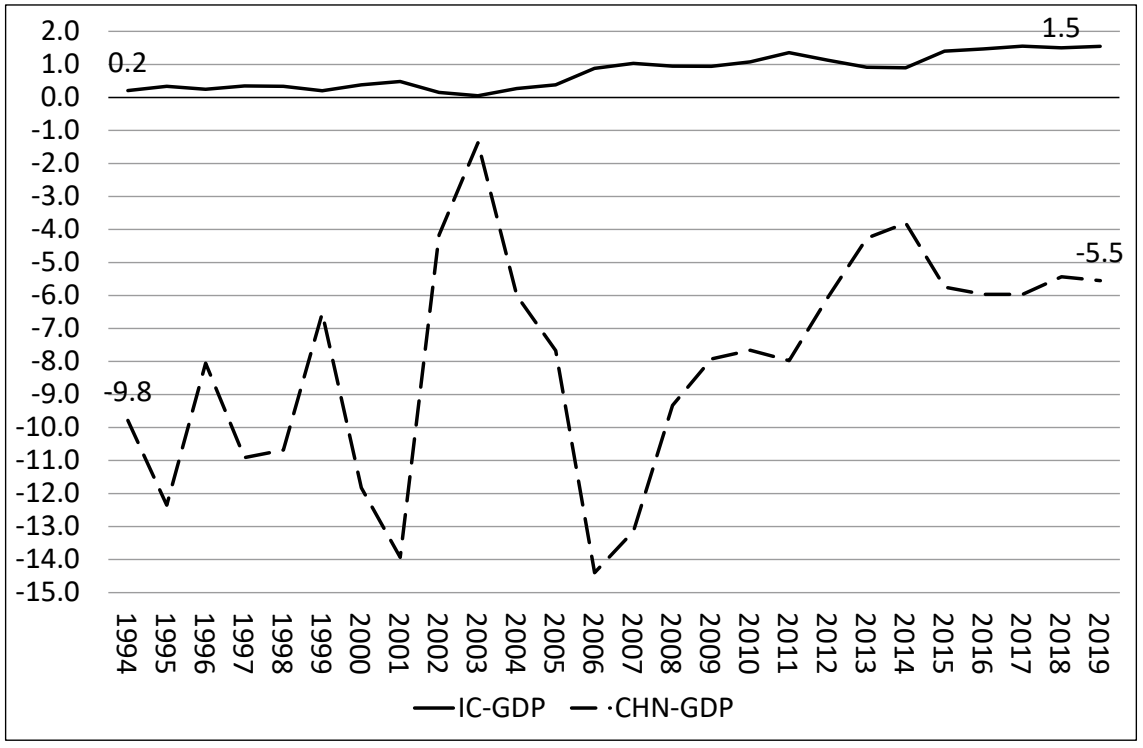

FIGURE 22 Transfer of surplus value between China and the IC bloc as \% of GDPs SOURCE: PENN WORLD TABLES 10.0, APPENDIX 2

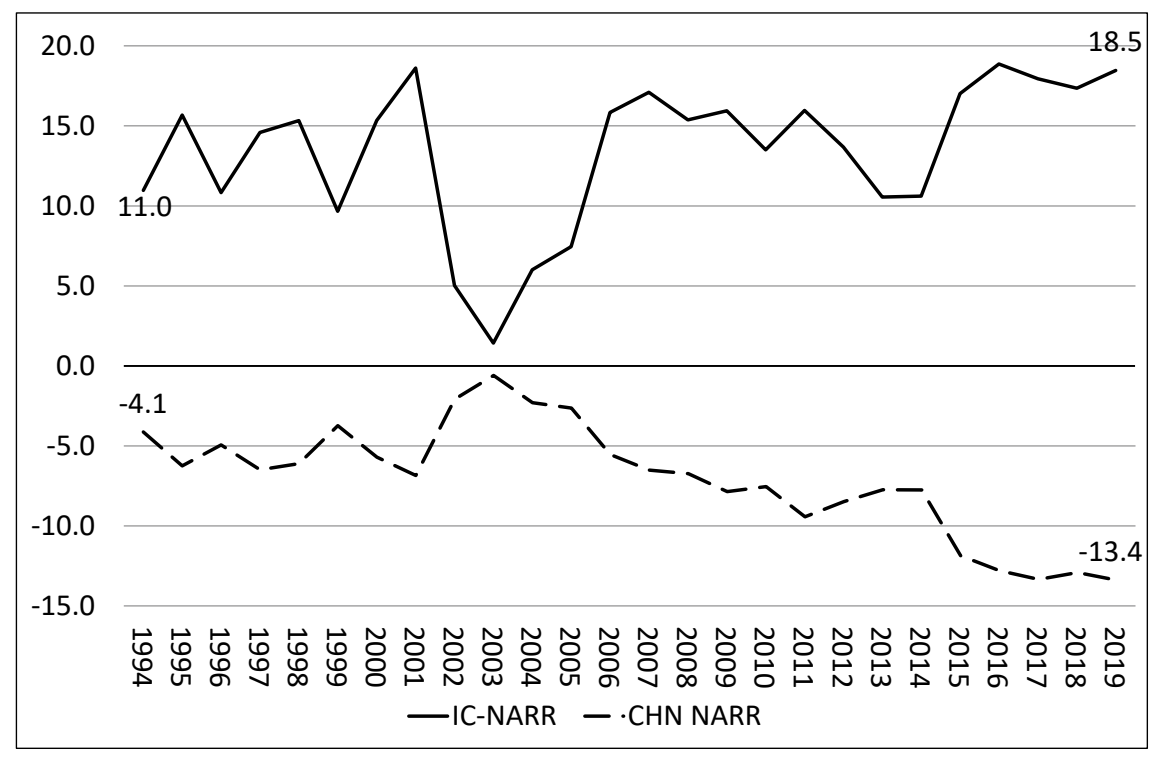

FIGURE 23 Transfer of surplus value between China and the IC as share of export profits (\%) SOURCE: PENN WORLD TABLES 10.0, APPENDIX 2

Indeed, China's negative UE transfer to IC averages over $6 \circ \%$ of its annual exports to the IC (Figure 24). 
When we measure the broad UE, it also shows a huge transfer of surplus value that the IC bloc gets from the rest of the DC, but it also shows that China gains little from the rest of the DC (Figure 25). The IC gained an average of $5 \%$ of its exports in UE in trade with China and the rest of DC, while China had a net loss on average of around $2 \%$ of its exports with the IC and the rest of

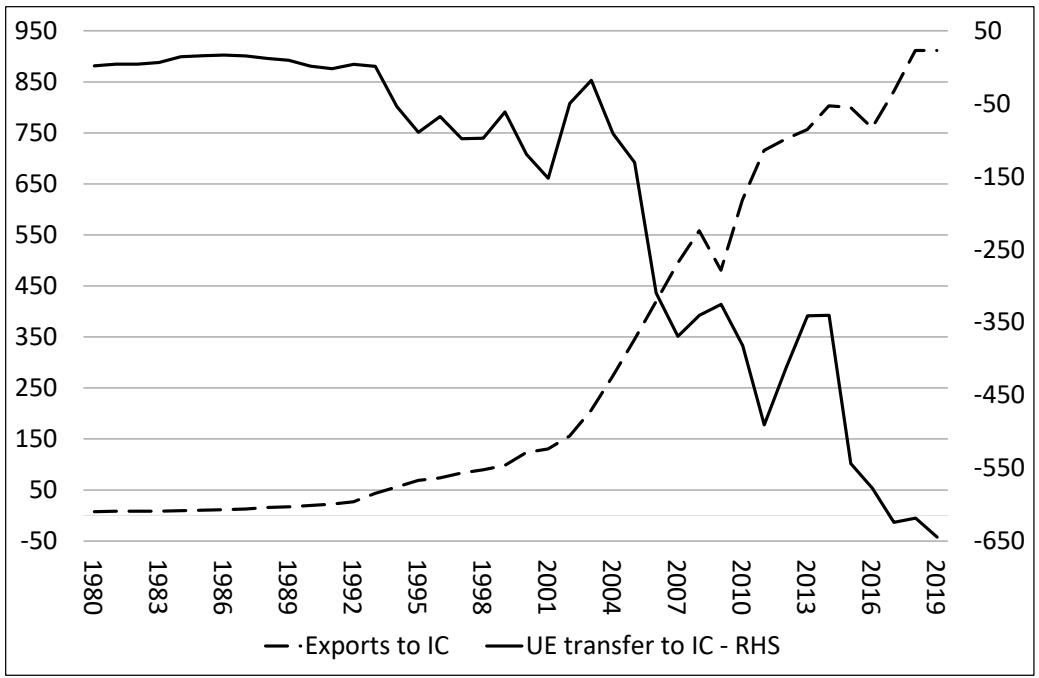

FIGURE 24 China's annual exports to IC and UE transfer, \$bn SOURCE: PENN WORLD TABLES 10.0, APPENDIX 2

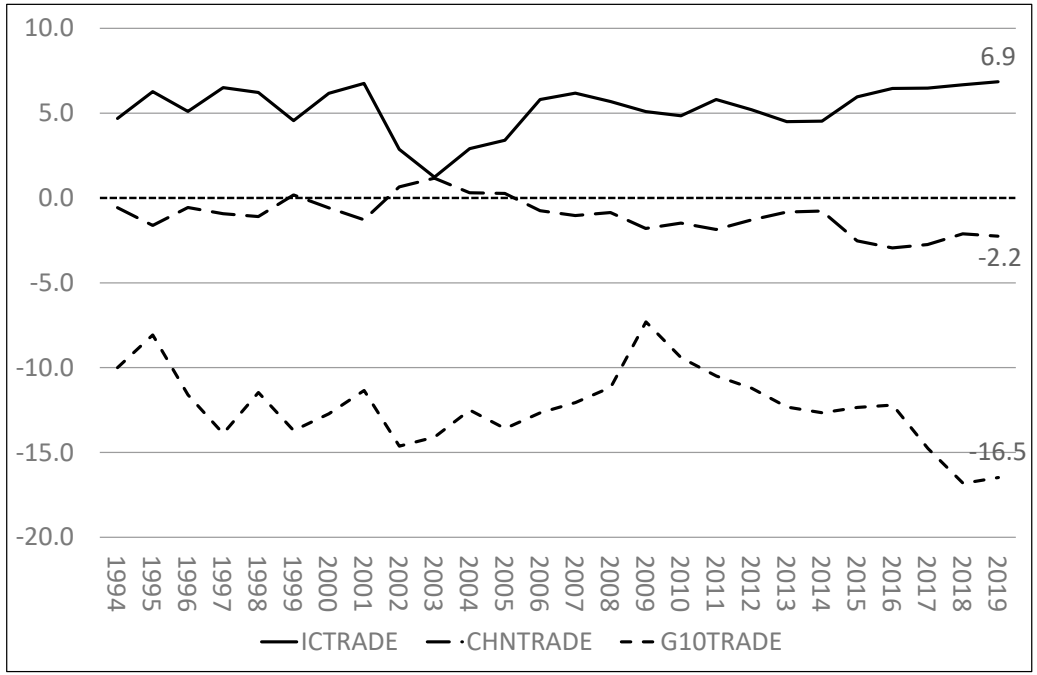

FIGURE 25 Transfer of surplus value between IC, China and rest of DC as share of trade for each (\%) SOURCE: PENN WORLD TABLES, APPENDIX 2 
the DC. The rest of the DC took an average hit to the equivalent of $15 \%$ of its exports to China and the IC.

This suggests that China gained little or nothing in surplus value from its trade with the rest of the DC. In conclusion, Figures 22-25 confirm that China is not an imperialist country by our definition; on the contrary, it clearly fits into the dominated bloc.

If we look at the net value transfer between China and the US alone, up to the 1990s, trade between the US and China was small and thus China's negative UE was limited. But after that, the annual transfer of surplus value from China to the US increased and rose to $6-8 \%$ of China's GDP (Figure 26). The result is similar for the broad UE measure. This is further evidence that China is still part of the group of the dominated countries.

The contribution to this surplus value transfer is more from the occ differential than from the RSv differential (59:41), although the occ contribution falls over time due to China's faster growth of fixed capital investments (Figure 27).

China's higher investment growth than the US is one reason for the small decrease in China's UE transfer to the US since 2007. The other is the slowdown in the two countries' trade after the end of the Great Recession. Between 1979 and 2007 , China's exports to the US increased by a staggering $28 \%$ on average each year. After 2007, China exports to the US rose only $7 \%$ a year. China has

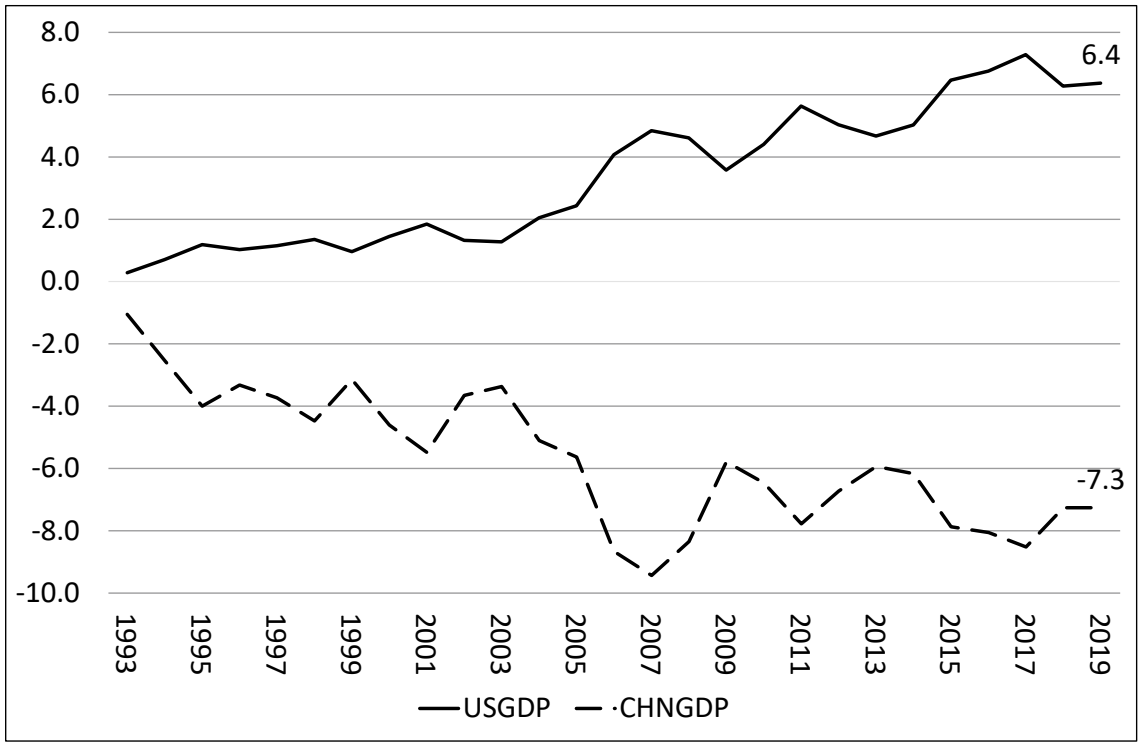

FIGURE 26 Annual net transfer of surplus value between the US and China (\% of country GDPs)

SOURCE: PENN WORLD TABLES 10.0, APPENDIX 2 


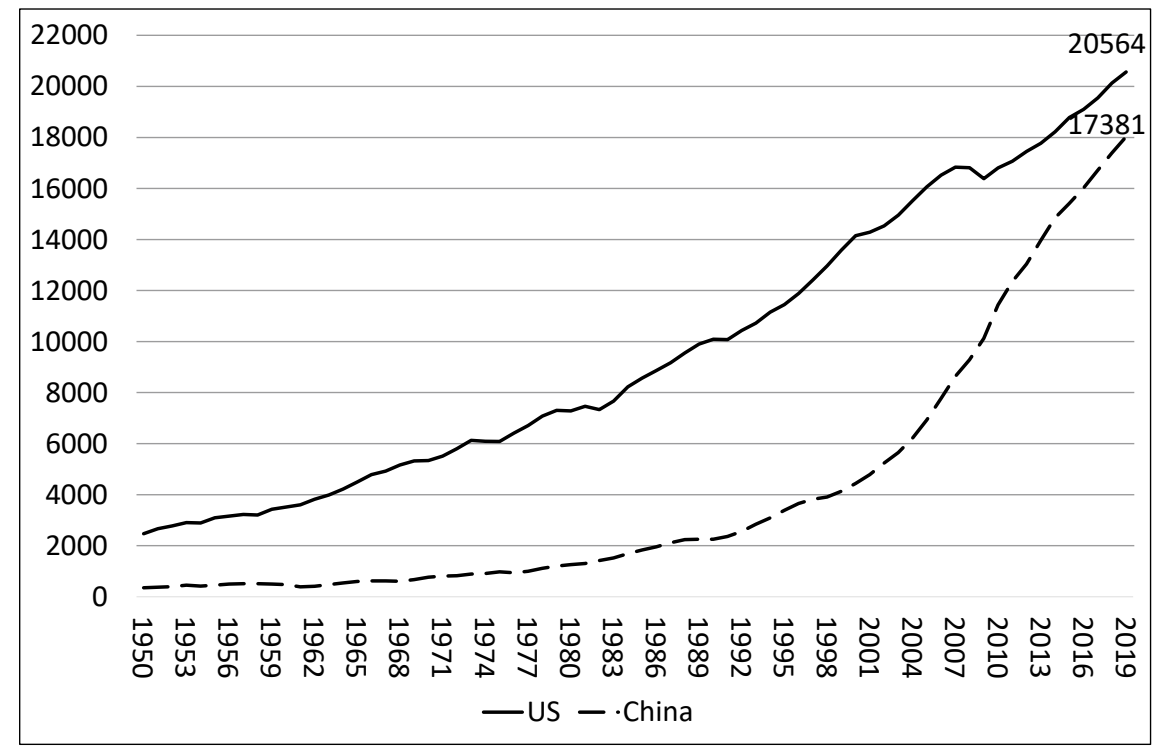

FIGURE 27 US-China, real fixed assets, \$bn SOURCE: PENN WORLD TABLES 10.0, AUTHORS' CALCULATIONS

been running a significant surplus in its balance of trade with the US. If China increases its capital accumulation more than the US and increases its exports to the US, its balance of trade improves ceteris paribus, but its UE worsens because China still has a lower level of productivity.

China has increased its capital accumulation more than the US, but it has still not reached the US level of technology. The technical composition ratio (capital stock to employees) of China to the US has narrowed over the last 70 years, but China's average productivity level is still less than $25 \%$ of that of the US (Figure 28).

Indeed, the US gains surplus value through UE with China from China's faster economic growth and export surpluses because of China's lower level of technology and thus productivity. This makes it clear that trade surpluses are not evidence of surplus value extraction. Indeed, the larger are exports by China to the US, the greater is the loss of surplus value to the US, and the less resources available for the former's own development, including the development and application of new more-advanced technologies. Due to its faster growth of fixed assets than the US, China's occ has risen. So we should expect its rate of profit to fall. And indeed, this is the case. Not only does it fall; it falls at a greater pace than in the US (Figure 29).

For an emerging capitalist nation there is no other way to 'development' than by raising productivity through more efficient technologies. But this 


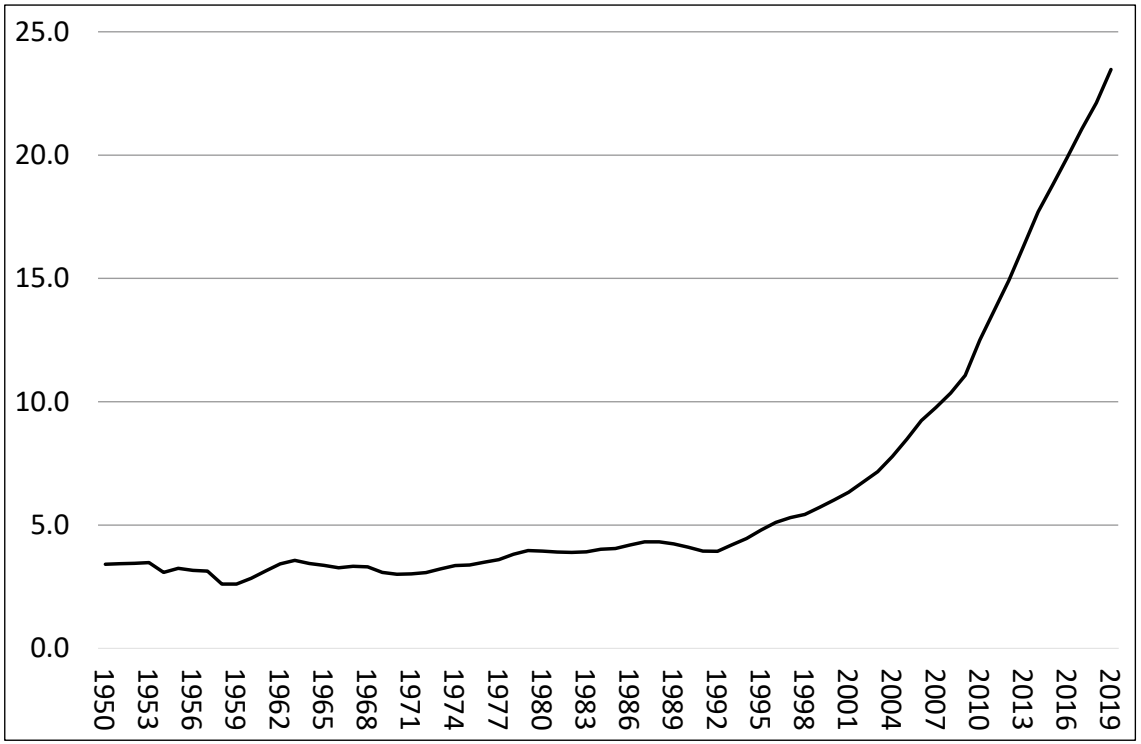

FIGURE 28 Ratio of technical composition of capital, China-US SOURCE: PENN WORLD TABLES 10.0, AUTHORS' CALCULATIONS, SEE APPENDIX 1

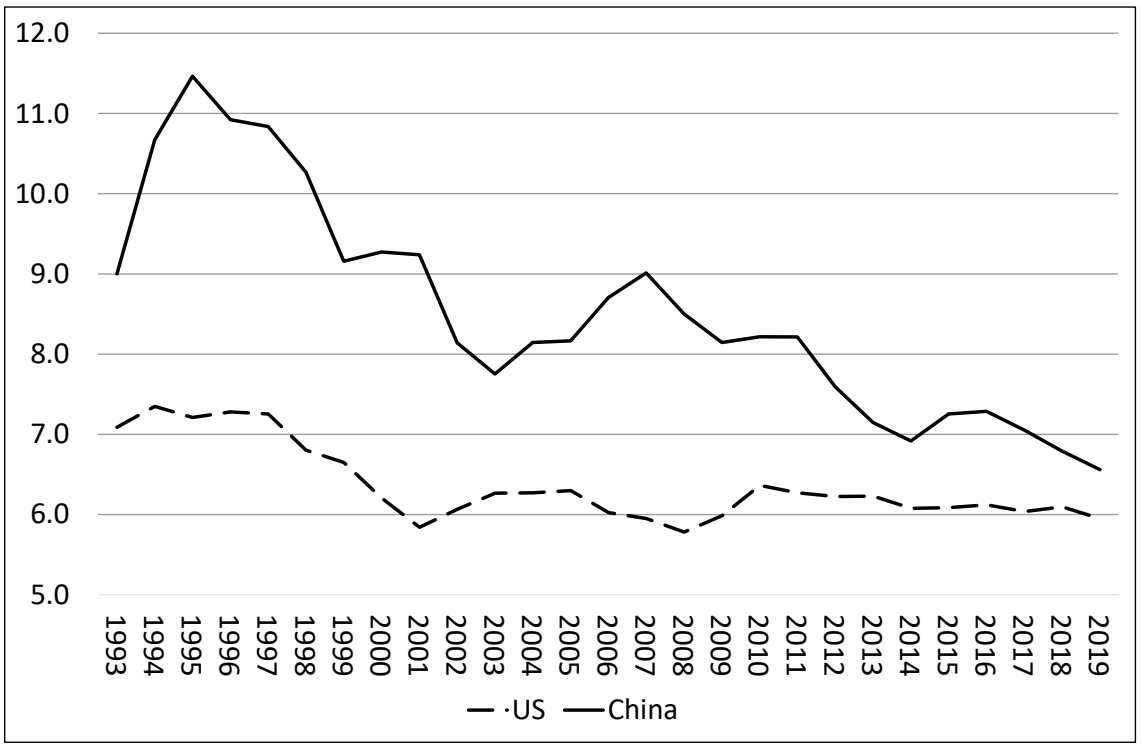

FIGURE 29 The rate of profit in China and the US (\%) SOURCE: PENN WORLD TABLES 10.0, AUTHORS' CALCULATIONS, SEE APPENDIX 1 
lowers profitability. Meanwhile, the dominated countries are not catching up fast enough to reduce the extraction of value through trade to the imperialist countries. This general conclusion applies to China as well.

\section{Conclusion}

To conclude, we have applied Marx's value theory to the international setting by developing this theory's inner logic and we have tested the results empirically. These are the two North Stars we have followed in our analysis of modern imperialism: logical consistency with Marx's value theory and robust empirical verification.

\section{Appendix 1: Sources and Methods for Figures}

Figure 1. Annual real GDP growth rate of G2o economies (\%)

Penn World Tables 10.0, GDP series rgdpna

Figure 2. Rate of profit in G2o economies (\%)

Penn World Tables 10.o: $\mathrm{S} / \mathrm{K}+\mathrm{V}$, where $\mathrm{K}=$ rnna; $\mathrm{V}=\mathrm{GDP}{ }^{*}$ labsh; $\mathrm{S}=\mathrm{GDP}-\mathrm{V}-\mathrm{c}$.

Figure 3. Annual real GDP growth in imperialist bloc (\%)

Penn World Tables 10.o, GDP series rgdpna for 8 economies

Figure 4. The rate of profit in imperialist bloc (\%)

Penn World Tables 10.0, S/K + V for 8 countries as calculated in Figure 2

Figure 5. The rate of profit in imperialist and dominated blocs (\%)

Penn World Tables 10.o, S/K + V for 19 countries as calculated in Figure 2

Figure 6. Technical composition of capital in the imperialist and dominated economies Penn World Tables 10.0, capital stock series rnna divided by number of employees series, emp

Figure 7. Organic composition of capital in the imperialist and selected dominated economies

Penn World Tables 10.0. K/V Capital Stock K = rnna*pl_n I; V = GDP = rgdpna*pl_gdpo*labsh 
Note: The Penn series labsh has been adjusted to take into account the size of the self-employed and informal workforce in many countries. We have used the estimates for adjusted labour share provided by the Asian Development Bank Institute (Guerriero 2019).

Guerriero's data are also found with the Institute for Development Policy and Management (IDPM) Development Economics and Public Policy Working Paper Series WP No. 32/2012 (Guerriero 2012). This adjusted labour share data goes back to 1970 and we have extrapolated the data for 1950-70, but excluded those years in Figure 7.

Figure 8. Ratio of average wages between the dominated countries and the imperialist G7 countries

Penn World Tables 10.0, Average wages $=\mathrm{v}$ (see above) divided by employees, emp

Figure 9. Net primary income flows to $\mathrm{G}_{7}$ imperialist countries $\$ \mathrm{bn}, \%$ of $\mathrm{G}_{7} \mathrm{GDP}$ IMF international financial statistics, World Development Indicators, World Bank, $<$ https://data.worldbank.org/indicator/BN.GSR.FCTY.CD>, plus GDP data from the IMF World Economic Outlook database, <https://www.imf.org/en/Publications/WEO/ weo-database/2020/October $>$.

Figure 10. Annual net primary outflows from dominated countries $\$$ bn As in Figure 9 for relevant countries.

Figure 11. Outward foreign direct investment stock (\$trn)

UNCTAD, <https://unctadstat.unctad.org/wds/TableViewer/tableView.aspx>.

Figure 12. US balance of trade in $\$ b n$ and as $\%$ of GDP

FRED, BOPGSTB series

Figure 13. Net transfer of US dollar notes to rest of world (\$bn)

Louwerse 2017

Figure 14. Currency share of global FX reserves (\%)

IMF COFER

Figure 15. UE transfer of surplus value between IC and DC as \% of bloc GDP s See Appendix 2.

Figure 16. UE transfer between the IC and DC as share of annual profits See Appendix 2. 
Figure 17. UE transfer between IC and DC as share of annual exports See Appendix 2.

Figure 18. Relative contribution of OCC and RSv to value transfer between IC and DC $(\%)$

See Appendix 2.

Table 3. Average transfer of value (\% of trade) for US-Mexico; and US-UK, 1950-2019 See Appendix 2.

Figure 19. US and Mexico TCC s and the exchange rate, 1994-2019

Source: Penn World Tables 10.0 and FRED DEXMXUS

Figure 20. US and Germany TCCs and XR, 1971-2001

Source: Penn World Tables 10.0 and FRED EXgEus

Figure 21. US and China TCCs and XR, 1994-2019

Source: Penn World Tables 10.0 and FRED

Figure 22. Transfer of value between China and the IC bloc (\% of GDP)

See Appendix 2.

Figure 23. Transfer of surplus value between China and IC bloc as share of export profits

See Appendix 2.

Figure 25. US-China trade balance and UE transfer \$bn

See Appendix 2.

Figure 26. IC-China broad UE transfer as \% of GDP

See Appendix 2.

Figure 27. US-China, real fixed assets $\$ b n$

Source: Penn World Tables 10.0

Figure 28. Ratio of technical composition of capital, China-US

Source: Penn World Tables 10.o.

Figure 29. The rate of profit (IRR) in China and the US (\%)

Penn World Tables 10.o, as measured in Figure 2 


\section{Appendix 2: Measuring UE: Methodology}

\section{Database series used}

We use the Penn World Tables 10.o for our raw data.

$<$ https://www.rug.nl/ggdc/productivity/pwt/>.

We use the following series in constant prices:

GDP = rgdpna

Capital Stock $\mathrm{K}=$ rnna

Depreciation ratio $=$ delta

Internal rate of return $=$ irr

The annual national market price $(\mathrm{MP})=$

$\mathrm{c}=$ capital used up $=\mathrm{K}^{*}$ delta

$\mathrm{S}=$ Capital stock rnna * internal rate of return on stock irr

$\mathrm{V}=\mathrm{GDP}$ rgdpna $-\mathrm{S}$

$\mathrm{MP}=\mathrm{c}+\mathrm{V}+\mathrm{S}$

To compute the annual UE transfer value in trade between two countries or blocs, we use the annual export to GDP ratios (x) for each country's trade with another. Exports between countries are sourced from the IMF Direction of Trade Statistics (<https:// data.imf.org/?sk=9d6o28d4-fi4a-464c-a2f2-59b2cd424b85>).

Export ratio $\mathrm{x}=$ exports/GDP.

Thus the annual national market output value (MPx) for exports between each country or bloc:

$\mathrm{MPx}=\mathrm{cx}+\mathrm{Vx}+\mathrm{Sx}$

\section{Some Theoretical Issues}

Productive vs. unproductive

The Penn Tables 10.o do not separate productive from unproductive sectors. However, this is not an issue here because we can assume that the export sectors are basically productive sectors.

\section{Estimating surplus value}

Within a country the national surplus value is value realised because it is the sum of the value realised by domestic sectors through the formation of a national rate of profit. So the surplus value before international realisation is the surplus value after national realisation. But within the international context the same several national surplus values are unrealised value and they must be further redistributed internationally through the formation of a world rate of profit. 
Estimating the rate of exploitation (RSV)

In the text we have argued that the formula for the rate of exploitation is $\mathrm{RSV}=(\mathrm{S}+$ UE)/V. This expands on Marx's formula RSV = S/V because we include the transfer of international surplus value.

\section{Calculating the Transfer Value of Unequal Exchange $(U E)$ in Trade}

We calculate UE in two ways: UE based on narrow bilateral trade (narrow UE) and UE based on broad trade (broad $U E)$.

\section{How to compute the narrow UE}

In the narrow UE, the assumption is that two countries trade only with each other.

The two countries' average rate of profit $(\mathrm{nRx})$ is:

$n R x=\left(S_{1 x}+S_{2} x\right) /\left(c 1 x+V_{1 x}+c 2 x+V 2 x\right)$

Given $n R x$, the two $n P P x$ are $(c x+V x)+(c x+V x)^{*} n R x$ for each country

Then the narrow UEx = nPPx-MPx for each country: The result will show + or - for each annual UEx, which will cancel each other out.

How to compute the broad UE.

In the broad $\mathrm{UE}$, the assumption is that the two countries trade with all other countries as well. So we take the G2o (actually 19) countries as the proxy for the world and calculate a world rate of profit based on these countries. The world average rate of profit (WRx) is thus

$\mathrm{WRx}=\Sigma \mathrm{Sx} /(\Sigma \mathrm{cx}+\Sigma \mathrm{Vx})$ for the 19 countries.

We compute the PPx:

Country 1. $\mathrm{PPx}=(\mathrm{cx}+\mathrm{Vx})+(\mathrm{cx}+\mathrm{Vx})^{*} \mathrm{WRx}$

Country 2. $\mathrm{PPx}=(\mathrm{cx}+\mathrm{Vx})+(\mathrm{cx}+\mathrm{Vx}) * \mathrm{WRx}$

Countries 17. $\mathrm{PPx}=\Sigma(\mathrm{cx}+\mathrm{Vx})+\Sigma(\mathrm{cx}+\mathrm{Vx})^{*} \mathrm{WRx}$

So the broad UEx = PPx-MPx for each country.

The result will show + or - for each UEx which will cancel out overall.

The difference between the narrow and the broad UE is found in the computation of the $n R x$ and WRx. 


\section{The Two Determinants of $U E$}

$\mathrm{UE}$ is determined by the difference between the organic composition of capital (OCC) and by the rate of surplus value (RSV) for each country. OCC $=K / V$ and RSV $=S / V+U E$. If the occ differentials are greater than the Rsv differentials, the former contribute more to the flow of value and vice versa.

\section{References}

Akkermans, Dirk H.M. 2017, 'Net Profit Flow per Country from 1980 to 2009: The Long-Term Effects of Foreign Direct Investment', PLoS ONE, 12, 6: eo179244, <https:// doi.org/10.1371/journal. pone.0179244>.

Altvater, Elmar, B. Blanke and Christian Neusiiss 1971, 'Kapitalistischer Weltmarkt und Weltwahrungskrise', Probleme des Klassenkampfs, 1: 5-117.

Amin, Samir 2015, 'Contemporary Imperialism', Monthly Review, 1 July, available at: <https://monthlyreview.org/2015/o7/o1/contemporary-imperialism>.

B EA 2016, Foreign Direct Investment by Country and Industry, available at: <bea.gov $>$.

Bond, Patrick 2018, 'East-East/North-South - or Imperial-Subimperial? The BRICS, Global Governance and Capital Accumulation', Human Geography, 11, 2:1-18.

Brown, Richard 1978, 'The Theory of Unequal Exchange: The End of the Debate?', Iss occasional papers, No. 65, The Hague: The Institute of Social Studies.

Busch, K., W. Scholler and W. Seelow 1971, Weltmarkt und Weltwahrungskrise, Bremen: Kuhlman.

Carchedi, Guglielmo 1991, Frontiers of Political Economy, London: Verso.

Carchedi, Guglielmo 2001, For Another Europe, London: Verso.

Carchedi, Guglielmo 2011, Behind the Crisis: Marx's Dialectics of Value and Knowledge, Historical Materialism Book Series, Chicago: Haymarket Books.

Carchedi, Guglielmo and Michael Roberts (eds.) 2019, World in Crisis: A Global Analysis of Marx's Law of Profitability, Chicago: Haymarket Books.

Cheng Enfu and Lu Baolin 2021, 'Five Characteristics of Neoimperialism: Building on Lenin's Theory of Imperialism in the Twenty-First Century', Monthly Review, 1 May, available at: <https://monthlyreview.org/2021/o5/o1/five-characteristics-of -neoimperialism/>.

Cockshott, Paul 2019, Comments on Michael Robert's blog post, 8 July.

Deubner, Christian, Udo Rehfeldt, Frieder Schlupp and Gilbert Ziebura 1979, Die Internationalisierung des Kapitals. Neue Theorien in der Internationalen Diskussion, Frankfurt am Main: Campus Verlag.

Duménil, Gérard and Dominique Lèvy 2011, The Crisis of Neoliberalism, Cambridge, MA: Harvard University Press.

Emmanuel, Arghiri 1972, Unequal Exchange: A Study of Imperialism in Trade, New York: The Monthly Review Press. 
Foster, John Bellamy 2015, 'The New Imperialism of Globalized Monopoly-Finance Capital, An Introduction', Monthly Review, 1 July, available at: < https://monthlyreview .org/2015/o7/o1/the-new-imperialism-of-globalized-monopoly-finance-capital/>.

Foster, John Bellamy 2019, 'Late Imperialism: Fifty Years after Harry Magdoff's The Age of Imperialism', Monthly Review, 1 July, available at: <https://monthlyreview .org/2019/o7/o1/late-imperialism/>.

Freeman, Alan 2019, "The Sixty-Year Downward Trend of Economic Growth in the Industrialised Countries of the World, University of Manitoba GERG Data Group Working Paper, No. 1.

Freeman, Alan and Guglielmo Carchedi (eds.) 2019, Marx and Non-Equilibrium Economics, Cheltenham: Edward Elgar Publishing.

Ghosh, Jayati 2019, 'A Brave New World, or the Same Old Story with New Characters?', Development and Change, 50, 2: 379-93.

Gibson, Bill 1980, 'Unequal Exchange: Theoretical Issues and Empirical Findings', Review of Radical Political Economics, 12, 3:15-35.

Grossmann, Henryk 1992, The Law of Accumulation and Breakdown of the Capitalist System: Being Also a Theory of Crises, translated and abridged by Jairus Banaji, London: Pluto Press.

Guerriero, Marta 2012, 'The Labour Share of Income around the World: Evidence from a Panel Dataset', Development Economics and Public Policy Working Paper Series No. 32/2012, Manchester: Institute for Development Policy and Management, available at: <https://hummedia.manchester.ac.uk/institutes/gdi/publications/working papers/depp/depp_wp32.pdf >.

Guerriero, Marta 2019, 'The Labor Share of Income around the World: Evidence from a Panel Dataset', AD B I Working Paper 920, Tokyo: Asian Development Bank Institute, available at: <https://www.adb.org/publications/labor-share-income-around-world -evidence-panel-dataset>; <https://www.adb.org/sites/default/files/publication/ 484346/adbi-wp92o.pdf $>$.

Herrera, Rémy, Zhiming Long, Zhixuan Feng and Bangxi Li 2020, 'Guerra commerciale USA-Cina: il vero ladro finalmente smascherato', Materialismo Storico, VIII, 1.

Hickel, Jason, Dylan Sullivan and Huzaifa Zoomkawala 2021, 'Plunder in the PostColonial Era: Quantifying Drain from the Global South through Unequal Exchange, 196o-2018', New Political Economy, 26, 6: 1030-47, <https://doi.org/10.108o/1356346 7.2021.1899153>.

Higginbottom, Andy 2013, 'Structure and Essence in Capital I: Extra Surplus-Value and the Stages of Capitalism', Journal of Australian Political Economy, 70, 70: 251-70.

International Trade Administration 2016, 'Jobs Attributable to Foreign Direct Investment in the United States', available at: <https://www.trade.gov/mas/ian/ build/groups/public/@tg_ian/documents/webcontent/tg_ian_oo5496.pdf>.

Jefferies, William 2019, 'Piero Sraffa's Physical Price System and Reproduction without Production', Capital \& Class, 44, 1: 63-83. 
Kalecki, Michał 1939, Essays in the Theory of Economic Fluctuations, London: George Allen and Unwin.

Katz, Claudio 2017, 'Aciertos y problemas de la superexplotación', available at: <https:// katz.lahaine.org/b2-img/ACIERTOSYPROBLEMASDELASUPEREXPLOTACIN.pdf>.

King, Samuel T. 2018, 'China and the Third World Are Not "Catching Up" to the Rich Countries', Labor and Society, 21, 4: 447-70.

King, Samuel T. 2020, Imperialism and the Development Myth: How Rich Countries Dominate in the Twenty-First Century, Draft.

Kohler, Gernot 1998, 'The Structure of Global Money and World Tables of Unequal Exchange', Journal of World-Systems Research, 4, 2: 145-68.

Kuhn, Rick 2007, Henryk Grossman and the Recovery of Marxism, Champaign, IL: University of Illinois Press.

Lenin, Vladimir Ilyich 1963 [1917], Imperialism, the Highest Stage of Capitalism, in Selected Works, Volume 1, Moscow: Progress Publishers.

Louwerse, J. 2017, International Seigniorage, The US Dollar and the American Trade Deficit, MSc thesis, Erasmus University, Rotterdam.

Maito, E. 2019, 'The Tendency of the Rate of Profit to Fall since the 19th Century and a World Rate of Profit', in Carchedi and Roberts (eds.) 2019, Chapter 4.

Marx, Karl 1867, 'On The Lausanne Congress', available at: <https://www.marxists.org/ archive/marx/iwma/documents/1867/lausanne-call.htm >.

Marx, Karl 1967, Capital, Volume I, New York: International Publishers.

Marx, Karl 1968, Theories of Surplus-Value. Part II, Moscow: Progress Publishers.

Marx, Karl 1976, Capital: A Critique of Political Economy. Volume One, translated by Ben Fowkes, Harmondsworth: Penguin.

Marx, Karl and Friedrich Engels 2010, Manifesto of the Communist Party, in Marx/ Engels Collected Works, Volume 6, London: Lawrence \& Wishart.

Mavroudeas, Stavros D. 2018, The Marxist Theory of Imperialism: Which Way Forward, Thirteenth Forum of the World Association for Political Economy, Berlin School of Economics and Law, 16-18 July.

Mavroudeas, Stavros D. and Stergios Seretis 2018, 'Imperialist Exploitation and the Greek Crisis', East-West Journal of Economics and Business, XXI, 1-2: 43-64.

Mayer, Adam 2018, 'Dissolving Empire: David Harvey, John Smith, and the Migrant', Review of African Political Economy, 10 April, available at: <http://roape.net/ 2018/o4/10/dissolving-empire-david-harvey-john-smith-and-the-migrant/>.

Nakajima, Akiko and Hiroshi Izumi 1995, 'Economic Development and Unequal Exchange among Nations: Analysis of the U.S., Japan, and South Korea', Review of Radical Political Economics, 27, 3: 86-94.

Norfield, Tony 2014, 'British Imperialism and Finance: A Contribution to the Theory of Contemporary Imperialism', doctoral dissertation, soAs, University of London. 
Norfield, Tony 2018, 'Finance, Imperialism and Profits', Economics of Imperialism, 12 November, available at: <https://economicsofimperialism.blogspot.com/2018/11/ finance-imperialism-and-profits.html >.

Norfield, Tony 2019, 'Imperialism, a Marxist Understanding', Socialist Economist, 30 July, available at: <http://www.socialisteconomist.com/2019/o3/imperialism-marxist -understanding.html>.

Patnaik, Utsa and Prabhat Patnaik 2015, 'Imperialism in the Era of Globalization', Monthly Review, 1 July, available at: <https://monthlyreview.org/2015/o7/o1/ imperialism-in-the-era-of-globalization/>.

Ricci, Andrea 2021, Value and Unequal Exchange in International Trade: The Geography of Global Capitalist Exploitation, London: Routledge.

Sawyer, Malcolm C. 1988, 'Theories of Monopoly Capitalism', Journal of Economic Surveys, 2, 1: 47-76.

Senf, B. 1978, 'Politische Ökonomie des Kapitalismus', Mehrwert, 18.

Shaikh, Anwar 2012, 'Competition Matters: China's Exchange Rate and Balance of Trade', The Forum, Summer: 82-4.

Shaikh, Anwar and Rania Antonopoulos 2013, 'Explaining Long Term Exchange Rate Behavior in the United States and Japan', in Alternative Theories of Competition: Challenges to the Orthodoxy, edited by Jamee K. Moudud, Cyrus Bina and Patrick L. Mason, London: Routledge.

Siegel, Tilla 1984, 'Politics and Economics in the Capitalist World Market: Methodological Problems of Marxist Analysis', International Journal of Sociology, 14, 1: 1-154.

Smith, John 2011, 'Imperialism and the Law of Value', Global Discourse [Online], 2: I, available at: <https://globaldiscourse.files.wordpress.com/2011/o5/john-smith.pdf > .

Smith, John 2016, Imperialism in the Twenty-First Century: Globalization, SuperExploitation, and Capitalism's Final Crisis, New York: The Monthly Review Press.

Smith, John 2018, 'Imperialist Realities vs. the Myths of David Harvey', Review of African Political Economy, 19 March, available at: <https://roape.net/2018/o3/19/imperialist -realities-vs-the-myths-of-david-harvey/>.

Sweezy, Paul M. 1942, The Theory of Capitalist Development: Principles of Marxian Political Economy, London: Dennis Dobson Ltd.

Tsaliki, P., Christina Paraskevopoulou and Lefteris Tsoulfidis 2018, 'Unequal Exchange and Absolute Cost Advantage: Evidence from the Trade between Greece and Germany', Cambridge Journal of Economics, 42, 4:1043-86. 